\title{
How to avoid eutrophication in coastal seas? A new approach to derive river-specific combined nitrate and phosphate maximum concentrations
}

\author{
Ménesguen Alain ${ }^{1,{ }^{*}}$, Desmit Xavier ${ }^{2}$, Dulière Valérie ${ }^{2}$, Lacroix Geneviève ${ }^{2}$, Thouvenin Benedicte ${ }^{1}$, \\ Thieu Vincent ${ }^{3}$, Dussauze Morgan ${ }^{4}$
}

${ }^{1}$ Department of Coastal Environment Dynamics (DYNECO), French Research Institute for Exploration of the Sea (IFREMER), Centre de Bretagne, B.P. 70, 29280 Plouzané, France

${ }^{2}$ Royal Belgian Institute of Natural Sciences (RBINS), Operational Directorate Natural Environments (DO Nature), Gulledelle 100, 1200 Brussels, Belgium

${ }^{3}$ UMR 7619 METIS, Sorbonne Universités, UPMC, Univ Paris 06, CNRS, EPHE, Paris, France

${ }^{4}$ ACTIMAR, 36, Quai de la Douane, 29200 Brest, France

*Corresponding author : Alain Ménesguen, email address : alain.menesguen@ifremer.fr

\begin{abstract}
:
Since 1950, increase in nitrogen $(\mathrm{N})$ and phosphorus $(\mathrm{P})$ river loadings in the North-East Atlantic (NEA) continental seas has induced a deep change in the marine coastal ecosystems, leading to eutrophication symptoms in some areas. In order to recover a Good Ecological Status (GES) in the NEA, as required by European Water Framework Directive (WFD) and Marine Strategy Framework Directive (MSFD), reductions in N- and P-river loadings are necessary but they need to be minimal due to their economic impact on the farming industry. In the frame of the "EMoSEM" European project, we used two marine 3D ecological models (ECO-MARS3D, MIRO\&CO) covering the Bay of Biscay, the English Channel and the southern North Sea to estimate the contributions of various sources (riverine, oceanic and atmospheric) to the winter nitrate and phosphate marine concentrations. The various distributed descriptors provided by the simulations allowed also to find a log-linear relationship between the 90th percentile of satellite-derived chlorophyll concentrations and the "fully bioavailable" nutrients, i.e. simulated nutrient concentrations weighted by light and stoichiometric limitation factors. Any GES threshold on the 90th percentile of marine chlorophyll concentration can then be translated in maximum admissible 'fully bioavailable' DIN and DIP concentrations, from which an iterative linear optimization method can compute river-specific minimal abatements of $N$ and $P$ loadings. The method has been applied to four major river groups, assuming either a conservative $(8 \mu \mathrm{g} \mathrm{Chl} \mathrm{L-1)}$ or a more socially acceptable $(15 \mu \mathrm{g} \mathrm{Chl} \mathrm{L-1)}$ GES chlorophyll concentration threshold. In the conservative case, maximum admissible winter concentrations for nutrients correspond to marine background values, whereas in the lenient case, they are close to values recommended by the WFD/MSFD. Both models suggest that to reach chlorophyll GES, strong reductions of DIN and DIP are required in the Eastern French and Belgian-Dutch river groups.
\end{abstract}




\section{Graphical abstract}

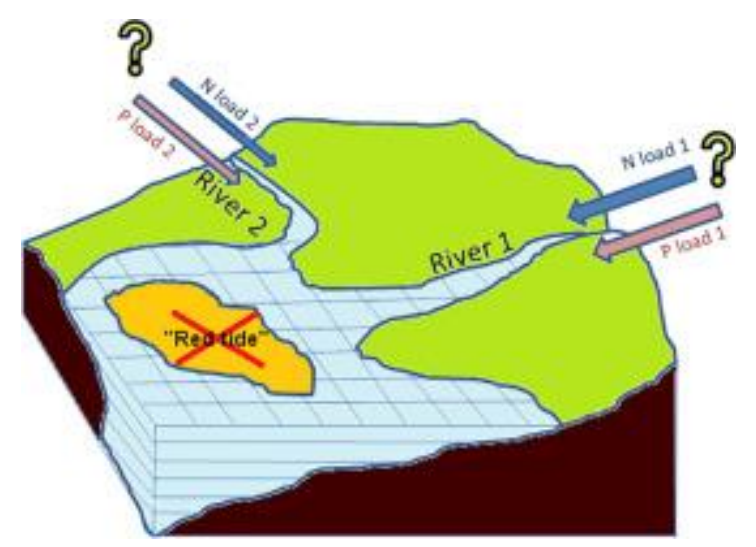

\section{Highlights}

$3 \mathrm{D}$ models of the European shelf provide the $\%$ of marine $\mathrm{N}$ and $\mathrm{P}$ coming from rivers. $\rightarrow \mathrm{A}$ G.E.S threshold for marine chlorophyll is derived from 2000 to 2010 satellite images. Simulated light and $\mathrm{N}: \mathrm{P}$ stoichiometric limitations define "available" nutrients. 90th percentiles of chlorophyll respond loglinearly to 'available' nutrients. Marine G.E.S threshold can be converted into optimum N- and Plevels in rivers.

Keywords: Marine eutrophication, Ecosystem modelling, Nutrient reduction scenario, Linear optimization, Good ecological status, EU policies 


\section{Introduction}

Since the middle of the $20^{\text {th }}$ century, coastal nutrient loadings from rivers and from atmospheric deposition in the case of nitrogen (Doney, 2010) have doubled at a global scale (Beusen et al., 2016). Locally, nutrient enrichment has increased even more severely in coastal waters of developed countries: Billen et al. (2011) mention that in European coastal waters, the current loads from major watersheds vary from 200 to $4000 \mathrm{kgN} \cdot \mathrm{km}^{-2} . \mathrm{yr}^{-1}$ (mean: 810), which is about four times the natural background levels. This has induced eutrophication of some vulnerable marine areas. The most common symptom consists in the occurrence of intense summer blooms after the usual spring one (Kemp et al., 2005). Sometimes, decay of this algal organic matter can lead to a dramatic decrease of dissolved oxygen in the bottom waters, which causes the so-called and feared "dead zones" (Diaz and Rosenberg, 2008). In Europe, recent improvements following EU legislations in urban waste treatment (using denitrification and dephosphatation) induced a measurable reduction of point source emissions (especially phosphorus) but not of non-point ones (Artioli et al. 2008), so that nowadays, the main source of current loadings is the leaching from over-fertilized farming lands, especially for nitrogen.

One of the leading challenges to mitigate eutrophication nuisances in the EU seas is to improve scientific guidance so as to support effective region-specific management measures. Only a few approaches integrate the eutrophication process in space (river-ocean continuum, as in Bouwman et al., 2013) and in time (past, present and future status, as in Cugier et al., 2005). Setting river-specific load reductions remains complex because (I) consistent and harmonized reference levels assigned to each marine eutrophication-related indicator are lacking (Troost et al., 2013), (II) the merging at sea of river plumes of various magnitude and coming from different countries must be taken into account (Los et al., 2014; Dulière et al., 2017). To help addressing these issues, this study was done in the frame of the so-called

EMoSEM European Seas-ERA project (2013-2015, http://odnature.naturalsciences.be/emosem), which had been designed to meet four 
objectives: (I) to propose consistent threshold values for indicators of Good Ecological Status (GES), (II) to link the eutrophication nuisances in specific marine regions of the North-East Atlantic (NEA) to river anthropogenic inputs, (III) to trace back their sources up to the watersheds, then (IV) to explore watershed-specific nutrient reduction options that can help to reach GES.

To achieve these objectives, state-of-the-art modelling tools describing the river-ocean continuum in the NEA continental seas were improved and combined. Three marine ecological models, PCOMS (Mateus et al. 2012) for the Portugal-Spain area, ECO-MARS3D (Lazure and Dumas 2008; Ménesguen et al., submitted ${ }^{b}$ ) for the Bay of Biscay-English Channel area, MIRO\&CO (Dulière et al., 2017) for the eastern English Channel-Southern North Sea area) were adapted and coupled to a new generic ecological model for European river-basins (PyNuts-Riverstrahler, Thieu et al. submitted). Alternative scenarios were designed to estimate natural and anthropogenic nutrient contributions to the watersheds under pristine conditions (simulated from a situation where Europe is covered with forests without any human impact), for current times, and under three future plausible nutrient reduction scenarios: (I) completing the waste water treatment in accordance with the European legislation on point sources defined by the Urban Wastewater Treatment Directive (UWTD), (II) completing the waste water treatment and adopting good agricultural practices, (III) turning to a local, organic farming and halving animal proteins consumption, following a so-called demitarian diet. Before detailing these scenarios, Desmit et al. (submitted, this issue) have mapped common eutrophication indicators (e.g. winter dissolved inorganic nitrogen (DIN hereafter) and phosphate (DIP hereafter); $90^{\text {th }}$ percentile of March-October chlorophyll a concentrations (Chl P90 hereafter)) from model outputs integrated over the whole NEA. Background values of these indicators were estimated from model outputs under the pristine scenario. Areas subjected to anthropogenic eutrophication were identified based on differences between current and pristine situations. Based on Chl P90, severely impacted areas cover the French coastal zone in the Bay of Biscay, the plume of the Seine River and the Belgian and Dutch coastal zones. Less intense eutrophication occurs along the 
Portuguese coasts and offshore in the English Channel and the Southern Bight of the North Sea. Finally, results of nutrient reduction scenarios showed that only the Local-OrganicDemitarian scenario, which implies profound structural changes in the agro-food system (Billen et al. in press), significantly reduces seawards nitrogen fluxes so as to improve the eutrophication status of coastal areas.

Identifying the thresholds used to define the GES of marine waters is challenging (Devlin et al., 2007) and not clear-cut so far: official national thresholds vary between adjacent countries (Dworak et al., 2016). The Intersessional Correspondence Group on Eutrophication Modelling (ICG-EMO) working in the frame of the Oslo-Paris Convention (OSPAR) defined in his first workshop, unique and ubiquitous target thresholds for nutrients by considering winter values of DIN and DIP as two independent controlling factors (Baretta-Bekker et al., 2008). The two major drawbacks of this naive approach are: (I) DIN and DIP are not totally available to algae: based on Redfield stoichiometry between carbon, nitrogen and phosphorus in phytoplankton, the most limiting nutrient restricts the availability of the other nutrient for algal growth; consequently, DIN and DIP should be treated together (Paerl, 2009), in a distributed manner with respect to their local ratio. (II) High concentrations of DIN and DIP are not harmful by themselves but they can, under certain circumstances, affect other biogeochemical indicators (chlorophyll, oxygen concentration), which induce undesirable effects. Therefore, reduction in river nutrients should be estimated based on relevant eutrophication indicators, such as chlorophyll $a$, dissolved oxygen or abundance of toxic phytoplanktonic species. So, in addition to the traditional, bottom-up approach using scenarios on watersheds to force marine models and simulate ecological outcomes, this paper aims at improving the inverse top-down approach, starting from a GES constraint on a relevant indicator of eutrophication status (here Chl P90) to infer watershed-specific DIN and DIP maximum admissible concentrations. In complement to the framework developed by the OSPAR ICG-EMO working group (Los et al., 2014) that only used available time-series of measured nutrients closest to river mouths to force marine biogeochemical models, this approach incorporates the watershed-coastal sea integrated modelling exercise. In its 
bottom-up approach (i.e. forcing the marine models by time-varying outputs from the PyNutsRiverstrahler watershed model under various scenarios) as well as in its top-down approach (this study), the EMoSEM project has considered stable loadings and does not estimate recovery time to GES in case of loading reduction.

\section{Material and methods}

\section{- Marine ecological models used}

Two marine biogeochemical models were juxtaposed to cover the continental shelf from Biscay up to the Rhine estuary. The spatial extent of the Belgian one falls within the coverage of the French one, so outputs of these two models can be compared in this area where eutrophication is particularly intense, due to the cumulated effects of Seine, Scheldt and Rhine river plumes.

The application of the French ECO-MARS3D model, which is based on IFREMER's MARS3D hydrodynamical code (Lazure and Dumas 2008), covers the French Atlantic shelf using a regular $4 \times 4 \mathrm{~km}$ horizontal grid and 30 sigma vertical levels. The model domain includes the Bay of Biscay, the English Channel and the southern Bight of the North Sea and extends from $8.13^{\circ} \mathrm{W}$ to $5.0^{\circ} \mathrm{E}$, and from $43.17^{\circ} \mathrm{N}$ to $52.75^{\circ} \mathrm{N}$ (Figure 1, black rectangle). In order to improve the accuracy of oceanic currents and the biogeochemical fluxes at the western boundary of this domain, and to avoid local artificial enrichment through zero derivative boundary conditions, this grid has been embedded in a wider one, extending from $41^{\circ} \mathrm{N}$ to $55^{\circ} \mathrm{N}$ and $18^{\circ} \mathrm{W}$ to $9^{\circ} 30^{\prime} \mathrm{E}$, with also $4 \times 4 \mathrm{~km}$ meshes and 30 sigma levels. $\mathrm{A}$ preliminary run of this broader model provided hydrodynamic boundary conditions (sea surface elevation and 3D currents) along with biogeochemical fluxes at the boundaries of the small domain at each time step for the 2000-2010 decade.

By default, the ECOMARS3D marine biogeochemical model simulates 17 state variables to describe nitrogen, phosphorus and silicon cycles as well as dissolved oxygen in the pelagic ecosystem. Three limiting dissolved inorganic nutrients are considered: nitrogen (nitrate and 
ammonium being considered separately), phosphorus, and silicon. Phytoplankton is divided into three groups: diatoms, dinoflagellates and nanoflagellates, with concentrations expressed in nitrogen currency. To assess the specific consequences of eutrophication, a module simulating the single-cells, colonial forms and mucus of the haptophyte Phaeocystis globosa (inspired from the MIRO\&CO model developed by Lacroix et al., 2007) was added to the default phytoplankton model community. Total chlorophyll is estimated from nitrogenous state variables using an empirical $\mathrm{Chl} / \mathrm{N}$ ratio, computed following a Smith-like formula (Smith, 1936) to account for local light extinction. Two zooplanktonic components, expressed in nitrogen currency, are explicitly represented: the microzooplankton, which feeds on nanoflagellates, dinoflagellates and detrital particulate matter everywhere, along with diatoms in oceanic regions (depth>200 m), and the mesozooplankton, which grazes on diatoms, dinoflagellates and microzooplankton. In the model, diatoms are assumed to sink, while nanoflagellates and dinoflagellates can actively maintain their vertical position in calm water thanks to motility. Three particulate detrital variables (detrital N, detrital P, detrital Si) close the biogeochemical cycles, and settle in the water column; in the bottom layer, each settling fraction is partially transferred to a fixed state variable that represents the seafloor compartment, which can feed some particulate material back to the water column via erosion by currents, and some dissolved nutrients via remineralisation. The detailed description of the ECO-MARS3D model can be found in Ménesguen et al. (submitted ${ }^{\text {b }}$.

The Belgian MIRO\&CO model (Lacroix et al., 2007) results from coupling the 3D hydrodynamic COHERENS v2 model (Luyten 2011) with the biogeochemical MIRO model (Lancelot et al. 2005). The MIRO\&CO model describes biogeochemical and ecological dynamics in the southern North Sea. The model domain covers the English Channel and the Southern Bight of the North Sea from $4^{\circ} \mathrm{W}$ to $5.0^{\circ} \mathrm{E}$, and from $48.5^{\circ} \mathrm{N}$ to $52.5^{\circ} \mathrm{N}$ (Figure 1, red rectangle). The model has been implemented on a regular grid with $5.6 \times 4.6 \mathrm{~km}$ meshes and 5 sigma levels.

The MIRO biogeochemical model was designed for Phaeocystis-dominated ecosystems, and integrates 4 modules describing: (I) the dynamics of phytoplankton (diatoms, autotrophic 
nanoflagellates and Phaeocystis colonies), (II) zooplankton (microzooplankton and copepods), (III) bacteria and dissolved and particulate organic matter degradation and (IV) nutrient regeneration in the water column and the sediment (nitrate, ammonium, phosphate and dissolved silica). Phaeocystis free-living cells are included in nanoflagellates, while Phaeocystis colonies are described by the sum of 2 components: colonial cells and the polysaccharide matrix in which the cells are embedded and which serves as a reserve of energy. The degradation of organic matter by planktonic bacteria is described according to the HSB model (High polymers, Small substrates and Bacteria) of Billen and Servais (1989), considering two classes of biodegradability for DOM and POM. The hydrolysis of these polymers produces dissolved monomers that can be taken up by bacteria. Benthic organic matter degradation and nutrient $(\mathrm{N}, \mathrm{P}, \mathrm{Si})$ recycling are calculated by the algorithms developed by Lancelot and Billen (1985) and Billen et al. (1989). A full description of the modules and a schematic representation of the MIRO model can be found in Lancelot et al. (2005). A first version of the coupled MIRO\&CO model was detailed and validated in Lacroix et al. (2007). The version 2 used in the current study is detailed in Dulière et al. (2017). A validation can be found in Desmit et al. (2015a) and (Dulière et al., 2017).

\section{- Forcing data used}

For their hydrodynamical part, both marine models need tidal forcing at their marine boundaries and meteorological forcing at the sea surface, along with river discharges. For their biogeochemical part, they need river nutrient loadings, boundary values and initial fields for biogeochemical state variables.

Wind, atmospheric pressure and thermal fluxes at the sea surface are provided every 6 hours by meteorological models (at a $30 \mathrm{~km}$ resolution for the Arpege model of MétéoFrance used for the ECO-MARS3D model, and at a $60 \mathrm{~km}$ resolution for the UK Meteorological Office model used for MIRO\&CO). Whereas ECO-MARS3D computes sea surface temperature from meteorological forcing, MIRO\&CO forces the weekly sea surface temperature with a field $(20 \mathrm{~km} \times 20 \mathrm{~km}$ mesh) provided by the $\mathrm{BSH}$ (Bundesamt für Seeschiffahrt und Hydrographie) after interpolation on the model grid. 
Suspended particulate matter is forced by a fortnightly climatology distribution of Total Suspended Matter (TSM) derived from satellite MODIS-Aqua data (Gohin, 2011) for ECOMARS3D and by a daily TSM climatology derived from remote sensing observations over four years (2003-2006) and gap-filled with DINEOF method (Sirjacobs et al., 2011) for MIRO\&CO.

Simulated daily river discharges as well as 10-day river temperatures and biogeochemical variable concentrations are provided by the French Riverstrahler model (Billen et al. 1994; Garnier et al., 2002) with the PyNuts environment (Thieu et al. submitted).

At the marine boundaries, both models assume a zero horizontal cross boundary gradient conditions for all the biogeochemical state variables, except for inorganic nutrients $\left(\mathrm{NO}_{3}\right.$, $\left.\mathrm{NH}_{4}, \mathrm{PO}_{4}, \mathrm{Si}(\mathrm{OH})_{4}\right)$ and phytoplankton groups, in order to maintain an oceanic forcing at the basis of the food web which remains independent from the watershed loading scenario. Whereas MIRO\&CO uses databases compiled by the European Union NOWESP and ERSEM projects (Radach and Lenhart 1995) or time-series provided by the French SOMLIT ASTAN station (Lacroix et al., 2007), ECO-MARS3D uses boundary estimates from a spatially extended version of the model itself.

Monthly atmospheric nitrogen deposits (wet and dry, oxidized and reduced) for the period 2000-2010 are taken from the "European Monitoring and Evaluation Program (EMEP)" (http://www.emep.int/, courtesy of Semeena Valiyaveetil and Jerzy Bartnicki, Norwegian Meteorological Institute).

Model calibration against recent observations (i.e. the so-called "Reference" 2000-2010 period) was performed after a spin-up period of at least 3 years, which is necessary to smooth out the coarse initial conditions and for the large plumes to propagate all over the domain, and in particular within the slow-responding benthic compartments. The validation of the Reference situation of the two marine models is detailed in Desmit et al. (submitted, this issue). 


\section{- Determining sound thresholds for Good Ecological Status based on marine}

\section{eutrophication indicators}

The top-down approach proposed in this study first requires to translate the Chl P90 values in "fully bioavailable" DIN (or DIP) concentrations. To establish an invertible relationship between "fully bioavailable" nutrients and Chl P90, we have tried to explain for each mesh (i,j) of the model, the target variable Chl $\mathrm{P} \mathrm{i}_{\mathrm{i}, \mathrm{j}}$, i.e. the $\mathrm{P} 90$ of $2000-2010$ satellite-derived time-series of surface chlorophyll a (Figure 2), by various distributed surface outputs of the ECO-MARS3D model over the $2000-2010$ decade. As algal accumulation is locally driven by 3 factors (light availability, nutrient availability and residence time), the "fully bioavailable" DIN (or DIP) concentration in every mesh of the biogeochemical marine model (i.e. the proportion of model DIN or DIP available to algal growth) should take into account these limiting factors. However, due to the ambiguous definition of residence time (what water volume should we take into account?), we have only considered light and nutrient limitations as follows. Let be:

- $\quad$ DIN $_{i, j}$ and DIP $i, j$ the concentrations of DIN and DIP simulated in the mesh $(i, j)$ of the model and averaged on the winter period (January-February) of the 20002010 decade;

- $\mathrm{k}_{\mathrm{i}, \mathrm{j}}$ : the satellite-derived light extinction coefficient due to particulate inorganic matter, computed from MODIS spectral data according to Gohin (2011) and averaged over the productive period (March-October) of the 2000-2010 decade;

- $H_{i, j}$ the simulated mixed layer depth, i.e. the depth of main inflexion in water density vertical profiles computed by the ECO-MARS3D marine model, and averaged over the productive period (March-October) of the 2000-2010 decade.

Then, the light limitation factor in mesh $(i, j)$ is:

light_lim $\operatorname{li}_{i, j}=\left[1-\exp \left(-\mathrm{k}_{\mathrm{i}, \mathrm{j}}{ }^{*} \mathrm{H}_{\mathrm{i}, \mathrm{j}}\right)\right] /\left(\mathrm{k}_{\mathrm{i}, \mathrm{j}}{ }^{*} \mathrm{H}_{\mathrm{i}, \mathrm{j}}\right)$

the nutrient limitation factors in mesh $(\mathrm{i}, \mathrm{j})$ are:

nutrient_lim_DIN $N_{i, j}=\min \left(\operatorname{DIN}_{\mathrm{i}, \mathrm{j}}, 16{ }^{*} \operatorname{DIP}_{\mathrm{i}, \mathrm{j}}\right) / \operatorname{DIN}_{\mathrm{i}, \mathrm{j}}$

nutrient_lim_DIP $\mathrm{i}_{\mathrm{i}, \mathrm{j}}=\min \left(\mathrm{DIN}_{\mathrm{i}, \mathrm{j}} / 16, \mathrm{DIP}_{\mathrm{i}, \mathrm{j}}\right) / \mathrm{DIP}_{\mathrm{i}, \mathrm{j}}$ 
so, the "fully bioavailable" nutrients DIN_avail $\mathrm{i}_{\mathrm{j}, \mathrm{j}}$ and DIP_avail $\mathrm{i}_{\mathrm{i}, \mathrm{j}}$ in mesh $(\mathrm{i}, \mathrm{j})$ are:

DIN_avail $\left.\right|_{i, j}=$ DIN $_{i, j}{ }^{*}$ nutrient_lim_DIN ${ }_{i, j}{ }^{*} \operatorname{light}_{-} \lim _{\mathrm{i}, \mathrm{j}}$

DIP_avail $\mathrm{i}_{\mathrm{i}, \mathrm{j}}=$ DIP $_{\mathrm{i}, \mathrm{j}}{ }^{*}$ nutrient_lim_DIP $\mathrm{i}_{\mathrm{j}, \mathrm{j}}{ }^{*}$ light_lim $\mathrm{li}_{\mathrm{i}, \mathrm{j}}$

Converting simulated DIN and DIP concentrations into "fully bioavailable" fractions (DIN_avail, DIP_avail) is expected to rectify the relationship between nutrients and the target variable Chl P90, so that this new relationship can then be inverted over the full range of nutrients.

\section{- Tagging nutrients from various sources}

The pathways followed by a constituent in trophic web models can be investigated thanks to numerical tags attached to the state variables containing this constituent. If the trophic model is coupled to a spatially resolved model, the tagging technique will map the quantitative pathways followed by the constituent in the whole distributed trophic network. This technique has been used to track the various nitrogen sources leading to green algae mass accumulations (Ménesguen et al. 2006, Perrot et al. 2014) or phytoplankton blooms (Timmermann et al., 2010), but also for assessing the mean age and geographic origin of diatoms (Ménesguen et al. 1997). The tagging of the origin requires doubling all the differential equations of the model that involve the targeted constituent, as detailed below.

For the biogeochemical state variable $\mathrm{Bi}$, having the signature $\mathrm{S}(\mathrm{Bi})$ :

- the current mass evolution equation is:

$\mathrm{dBi} / \mathrm{dt}=\operatorname{sources}(\mathrm{B} 1, \mathrm{~B} 2, . . \mathrm{Bn}, \mathrm{t})-\operatorname{sinks}(\mathrm{B} 1, \mathrm{~B} 2, . . \mathrm{Bn}, \mathrm{t})$

- the new « signed mass » Bsi evolution equation is:

$\mathrm{dBsi} / \mathrm{dt}=\operatorname{sources}(\mathrm{B} 1, \mathrm{~B} 2, . . \mathrm{Bn}, \mathrm{t}) \times \mathrm{S}(\mathrm{B} 1$ source, $\mathrm{B} 2$ source,.. Bnsource $)-\operatorname{sinks}(\mathrm{B} 1, \mathrm{~B} 2, . . \mathrm{Bn}, \mathrm{t}) \times$ $\mathrm{S}(\mathrm{Bi})$

- the signature $\mathrm{S}(\mathrm{Bi})$ is:

$\mathrm{S}(\mathrm{Bi})=\mathrm{Bsi} / \mathrm{Bi}$

In the frame of the EMoSEM project, the ECO-MARS3D and MIRO\&CO models have been used to track along the whole trophic web and over their whole respective domains, the nitrogen (and simultaneously the phosphorus in ECO-MARS3D) coming from 6 different 
sources: the ocean (from the northern or western open boundaries), the atmosphere (only for nitrogen) and 4 groups of rivers (Figure 3) the so-called West-French rivers (i.e. the Loire River and the small rivers in Brittany), the East-French rivers (i.e. the Seine River and the small rivers in eastern English Channel), the English rivers (i.e. the Thames River and small rivers in southern England) and the Belgian-Dutch rivers (i.e. the Scheldt, the Rhine and the Meuse Rivers). In MIRO\&CO model this fourth group has been split into a Belgian group (i.e. the Scheldt, Leie and ljzer rivers, and 2 canals) and a Dutch group (i.e. the Rhine and the Meuse rivers) (see details in Dulière et al., 2017).

The tracking simulations quantify the contributions of different sources to marine nitrogen or phosphorus concentrations. Because these estimated contributions depend strongly on the current source concentrations, optimization of river nutrient loadings towards recovery of GES will change these source concentrations, the current maps of tracked nutrients must be converted into a mean map of the hydrological relative influence of the various sources, i.e. the percentages of water coming from the various sources. This can be done as follows. If $C_{i, j}$ is the marine surface concentration of a biogeochemical compartment averaged over the winter period (January-February) in the mesh $(\mathrm{i}, \mathrm{j})$ of the model grid, $\mathrm{f}_{\mathrm{k}}$ the fraction of the water coming from the $\mathrm{k}^{\text {th }}$ river in this mesh, $\mathrm{Cr}_{\mathrm{k}}$ the concentration of the targeted nutrient in the $\mathrm{k}^{\text {th }}$ river and Co its oceanic concentration, we can write the linear decomposition of the total concentration in mesh $(\mathrm{i}, \mathrm{j})$ as:

$C_{i, j}=\Sigma\left(f_{k} \cdot C r_{k}\right)+\left[1-\Sigma\left(f_{k}\right)\right] \cdot C o$

Otherwise, the tracking computation gives the components of the marine concentration $C_{i, j}$ coming from the various sources $\left(C_{k}\right.$ the concentration coming from river $k$, Co the background oceanic concentration):

$C_{i, j}=\Sigma\left(C_{k}\right)+C_{0}$

So, we can deduce the part of water in mesh $(\mathrm{i}, \mathrm{j})$ coming from the $\mathrm{k}^{\text {th }}$ river as:

$\mathrm{f}_{\mathrm{k}}=\mathrm{C}_{\mathrm{k}} / \mathrm{Cr}_{\mathrm{k}}$ 
Estimates of the fraction of water coming from the different rivers in each mesh should be consistent when computed using different conservative tracers, provided they are all dissolved. However, only winter DIN is always dissolved in the simulations, while DIP can become particular by adsorption and hence partially settle: this will tend to underestimate the spatial extent of river plumes. In consequence, estimates of the water fraction coming from the different rivers are based on simulated DIN concentrations only. This method was also usable across both models, given that the Belgian one had no P tracking implemented.

\section{- Optimising the river specific nutrient reductions to reach a global target}

The concept of "distance to target" (DTT) (Lenhart et al. 2013, Los et al. 2014) has been defined by the OSPAR ICG-EMO working group as the nutrient reduction necessary in the rivers to reach the eutrophication GES in a marine region. This is based on the hypothesis that high phytoplankton biomasses leading to eutrophication symptoms occur where nutrient concentrations are also high. In the ocean, such locations are usually found where natural upwellings occur and in plumes of enriched rivers. Even if widespread atmospheric deposition of $\mathrm{N}$ in the sea makes it a non-negligible source of nitrogen especially in offshore areas, as previously shown by Troost et al. (2013) and Dulière et al. (2017), the present study only focuses on river loads, which are the easiest nutrient inputs to control.

As river plumes can overlap and lead to local accumulation of nutrients, it is crucial to discriminate the contribution of large and remote sources relative to weak, local sources to local eutrophication in a given area. If we can linearize the link between river nutrients loads and an indicator of marine eutrophication, the problem of estimating the best cost-effective river-specific nutrient reduction in order to reach the target everywhere can be solved thanks to the linear optimization technique called the Simplex method (Dantzig 1963, Los et al. 2014). The technique consists in choosing a linear criterion to be minimized (e.g. the sum of the reductions of nutrient concentrations imposed to the various rivers) while obeying to fixed constraints (e.g. the marine nutrient concentration must stay under a predefined threshold, river nutrients cannot be reduced under either natural, pristine-like concentrations, or a value constrained by economic feasibility). The original method deals with one optimisation 
criterion and a set of linear constraints applied to variables which do not change along the optimisation course. In our problem, if we want to optimize both $\mathrm{N}$ and $\mathrm{P}$ loadings, some constraints may be relaxed during the optimisation course and the criterion may become insensitive to the sources of a nutrient as the system can shift, due to incremental reduction in nutrient loadings, from being locally $\mathrm{N}$-limited to P-limited, or vice-versa. In other words, the fact that nitrogenous variables may alter the values of phosphorus variables or vice-versa in the criterion introduces a non-linearity in the optimisation process, which violates the linear paradigm of the Simplex algorithm. Fortunately, this drawback can be overcome by iterating the whole Simplex procedure until it converges towards a stable solution.

This optimal search can be performed for different marine indicators (DIN and DIP separately or together, i.e. taking into account their ratio in the living matter, Chl P90 expressed in $\mathrm{N}$ or P currency, etc.). When DIN and DIP are optimised together (i.e., N/P constrained), the global function to be minimized is the sum of imposed concentration decrease in rivers for DIN and for DIP, but weighted by the N/P ratio, in order to equalize the weights of the two chemical elements $\mathrm{N}$ and $\mathrm{P}$.

The optimal nutrient reduction can also be estimated with reference to target-areas of different sizes (from WFD water masses up to MSFD sub-regions). Because the nutrients of the big rivers may be transported far away before complete dilution, not only coastal zones, but also remote offshore areas are sometimes subjected to undesirable eutrophication. As the size of the target-area can considerably modify the optimal nutrient reductions required, various target-areas have been tested.

\section{Results}

- Relationship between "fully bioavailable" nutrients and Chl P90

The daily SeaWiFS and MODIS satellite data for sea-surface chlorophyll a covering the 2000-2010 period have been gathered according to the $4 \times 4 \mathrm{~km}$ grid of the ECO-MARS3D, to map the 2000-2010 Chl P90 restricted to the OSPAR growing season (March- 
October inclusive) (Figure 2). The thickness of the surface mixed layer simulated by the ECO-MARS3D model and the satellite-derived light extinction coefficient have been daily combined and then averaged over the OSPAR growing season to assess the light limitation factor of phytoplankton growth. On the other hand, the simulated sum of nitrate and ammonia (Dissolved Inorganic Nitrogen DIN), as well as the simulated phosphate (Dissolved Inorganic Phosphorus DIP) have been averaged on the winter maximum enrichment period (January and February) to assess the initial stoichiometric nutrient limitation factors. As shown in Figure 4, taking into account the light-limitation only (grey dots) does not linearize the relationships between $\mathrm{Chl} P 90$ and the mean nutrient concentrations simulated by the ECOMARS3D model. However, by accounting for the joint nutrient- and light-limitations (black dots; Fig. 4), a rather good exponential relationship can be established between the "fully bioavailable" DIN or DIP and the observed Chl P90 $\left(r^{2}=0.7\right)$, when the two exponents are forced to respect the Redfield ratio $\left(16\right.$ molN.molP $\left.^{-1}\right)$. In contrast with the initial hyperbolic relation between overall nutrient concentrations and Chl P90 (grey points; Fig. 4), this exponential relation between available nutrients and Chl P90 is now mathematically invertible, and can be used to deduce "fully bioavailable" nutrient thresholds from imposed Chl P90 thresholds.

In order to minimize the arbitrary character of fixing a Chl P90 threshold value, we started from the density function of satellite-derived Chl P90 values in the marine meshes of the model (Figure 5). We have empirically decomposed this observed Probability Distribution Function (PDF) into the sum of four gamma theoretical PDFs; we observed that $8 \mu \mathrm{gChl. \textrm {L } ^ { - 1 }}$ corresponds to the abscissa where the contribution of the last gamma PDF begins to exceed this of the third PDF.

In a first application, we took a conservative point of view, considering that GES is no more

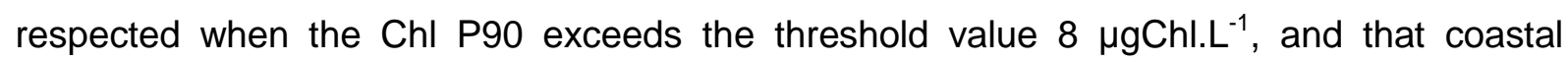
phytoplankton respects the oceanic Redfield ratio. Then, we deduced two conservative "fully bioavailable" DIN and DIP GES thresholds, as follows:

DIN threshold_rigorous $=\operatorname{Ln}(8 / 0.617) / 0.284 \approx 9.0 \mu \mathrm{mol} . \mathrm{L}^{-1}$ 
DIP threshold_rigorous $=\operatorname{Ln}(8 / 0.617) / 4.546 \approx 0.56 \mu \mathrm{mol}^{-L^{-1}}(=\mathrm{DIN}$ threshold_rigorous $/ 16)$

In a second application, we took a more "lenient" point of view, first keeping the official

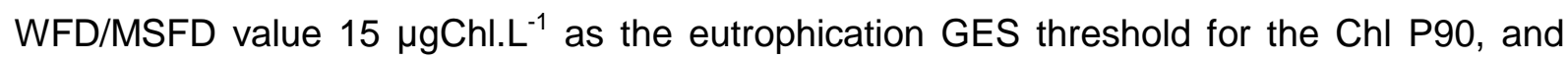
then considering that coastal phytoplankton has adapted its stoichiometry to $\mathrm{N}$-rich environments. In fact, the dataset of Belgian and Dutch historical campaigns suggests that the spring bloom formation requires a winter DIN:DIP ratio of about 30 molN.molP ${ }^{-1}$ in these coastal waters (Desmit et al. 2015b), a value which corresponds also to the upper limit of the DIN:DIP ratio recorded in the simulated "Pristine" scenario of river loadings by Desmit et al. (submitted, this issue). Thus, we obtained two other, lenient "fully bioavailable" DIN and DIP GES thresholds

DIN threshold_lenient $=\operatorname{Ln}(15 / 0.6814) / 0.1579 \approx 19.5 \mu \mathrm{mol} . \mathrm{L}^{-1}$

DIP threshold_lenient $=\operatorname{Ln}(15 / 0.6814) / 4.737 \approx 0.65 \mu \mathrm{mol}^{-L^{-1}}(=$ DIN threshold_lenient $/ 30)$

\section{- Contributions of various sources to $\mathbf{N}$ and $\mathrm{P}$ marine enrichment}

As total chlorophyll $a$ is a common metric for assessing the eutrophication level, we pooled the results obtained by the ECO-MARS3D model for its four phytoplanktonic state variables (diatoms, dinoflagellates, nanoflagellates and Phaeocystis globosa). For each nitrogen source, we computed the ratio of the 2000-2010 "growing season" mean of tagged phytoplankton over its corresponding biomass under the Reference scenario. This produces a unique map of decadal mean contribution of each source of nutrient to simulated marine phytoplankton biomass. Figure 6 shows that the contribution of oceanic fluxes entering through the boundaries remains dominant, except along the coast between the Seine and Rhine estuaries, where contributions by the Seine, Scheldt and Rhine Rivers impose a strong terrestrial influence. Atmospheric deposits contribute from 10 to $20 \%$ to overall marine nutrient concentration over the continental shelf. The nitrogenous contributions of the UK, as well as the Belgian-Dutch rivers are confined to the northern part of the domain, i.e. the southern North Sea and the Bristol Channel; UK contribution appears to be particularly limited to a short range. The group of Eastern French rivers, mainly driven by the Seine River, provides a high proportion of the phytoplankton requirements in the southern half of 
the Eastern English Channel, and accounts for $25 \%$ in the middle part of the Southern Bight of the North Sea. The group of Western French rivers exerts a long range influence mainly due to the Loire River: it spreads over a large part of the continental shelf, enters deeply in the English Channel and contributes to more than $10 \%$ of phytoplankton nitrogenous content entering the North Sea through the Strait of Dover.

The situation appears to be somewhat different for phosphorus. Figure 7 shows that the group of Western French rivers has a strongly reduced area of influence in terms of phytoplankton phosphorus compared to nitrogen. Conversely, the UK rivers exert a longer range influence for phosphorus than for nitrogen.

To arbitrarily change the nutrient concentrations in the final optimization phase, maps of current nutrient fractions coming from the different sources were converted to a map of relative contributions of water coming from the various sources. Figure 8 shows that the French and the Belgian models give comparable shapes of dilution plumes for the main river groups, with some marginal quantitative differences.

\section{- Optimum reduction of river nutrient loadings}

The conservative and "lenient" thresholds were used as targets in the Simplex procedure, first applied separately to the raw DIN (or DIP) linearly deduced from the dilution of river loadings, and then to their "fully bioavailable" components together.

As the required reduction in river loadings strongly depends on the geographical extent of the marine area in which the GES is to be reached, three different geographical targets have been used (Figure 9). A first one, the 0-50 m bathymetric strip along the coasts, is only based on a depth criterion, because eutrophication problems are known to occur in shallow waters. The second one refers to the national WFD marine water masses, whereas the third one refers to the French and Belgian MSFD sub-regions. The optimal sets of river DIN and DIP concentrations obtained by both models for three types of geographical targets are presented in Table 1.

Taking into account the light availability and the N/P ratio in the bioavailability of nutrients at sea reduces drastically the number of marine meshes exhibiting bioavailable nutrients above 
the GES thresholds in the current situation, hence it lowers considerably estimates of the optimal nutrient reductions necessary to reach GES. Figures 10 (for DIN) and 11 (for DIP) illustrate for the case of a wide geographical target (the MSFD French and Belgian subregions) the possibility to accept high DIN (respectively DIP) concentrations in certain zones because of the lack of DIP (respectively DIN) or because of high turbidity in these meshes.

Taking lenient GES thresholds for marine DIN and DIP instead of conservative thresholds significantly reduces the number of marine meshes considered as above these GES thresholds, which then relaxes several constraints on river nutrients. The groups of rivers concerned by nutrient reduction are identical in both cases, except for the UK group where a reduction in DIN is only required if adopting the conservative procedure.

Both ECO-MARS3D and MIRO\&CO models point mainly to the Eastern French and BelgianDutch groups of rivers as needing strong reductions of DIN as well as DIP. In the Eastern French group (i.e. the Seine group), DIN should be divided at least by 3 for MIRO\&CO (by 4 for ECO-MARS3D), DIP by 2 for MIRO\&CO (by 5 for ECO-MARS3D). In the Belgian-Dutch group, both models recommend halving the DIP loadings; for DIN, ECO-MARS3D requires at least halving the loadings (lenient thresholds) whereas MIRO\&CO recommends focusing only on the Rhine, with a reduction going from $25 \%$ (lenient thresholds) to $60 \%$ (conservative thresholds). The UK group (or Thames group) is only concerned if the target includes the UK coastal zone, i.e. if the full 0-50 m strip or the WFD marine water masses is considered.

\section{Discussion}

For several decades, the seek for useful, statistically-based relationships between nutrient supply and algal biomass has been a recurring question in lake, stream and river systems in order to provide operational tools to reduce eutrophication in these continental water bodies. The initial Organization for Economic Co-Operation and Development (OECD) work on lake 
eutrophication quantitative assessment (Vollenweider, 1975, Jones and Lee, 1986) has obtained a log-log linear relationship linking the chlorophyll a level to a synthetic combination of its main drivers, i.e. the loadings of the most limiting nutrient (DIP in lakes) and some lake physical indicators (depth and residence time). Surprisingly, in more recent attempts to predict algal biomass from nutrients, many authors (e.g. McCauley et al., 1989, Phillips et al., 2008) have replaced these causal variables by other explanatory variables such as total phosphorus (TP) or total nitrogen (TN) over the growing season, even if TP and TN contain the organic part of $\mathrm{P}$ or $\mathrm{N}$, which is linked to phytoplankton biomass and, hence, to chlorophyll a itself, the explained variable. In north-temperate lakes, these authors found that the relationship between chlorophyll $a$ and the first limiting nutrient was log-log linear only when the primary production was strongly limited by this nutrient (i.e. when total phosphorus stayed under $\left.100 \mu \mathrm{g} \cdot \mathrm{L}^{-1} \mathrm{TP}\right)$ but was sigmoid beyond this threshold, because of the increased limitation by a second nutrient, the total nitrogen in that case. This is similar to our findings of a log-log linear relationship between ChI P90 and DIN only below $15 \mu \mathrm{mol}^{-1}{ }^{-1}$ DIN, followed beyond this threshold by a saturating relationship due to other limiting factors $(N: P$ stoichiometry, light availability). For estuarine waters, Monbet (1992) also found a log-log linear relationship between chlorophyll $a$ and DIN concentrations extending from 4 to 400 $\mu \mathrm{mol} . \mathrm{L}^{-1} \mathrm{DIN}$, but he found that the dynamic processes associated with tidal range $(<2 \mathrm{~m}$ or $>2 m$ ) creates a Y-intercept shift in the log-log linear relationship rather than a departure from log-log linearity. In coastal marine waters, Desmit et al. (2015b) obtained significant linear relationships between chlorophyll a spring peak in the southern North Sea and efficient spring nutrients, i.e. winter DIN (or DIP) corrected by a dilution factor between winter and spring and by phytoplankton stoichiometric requirements. As the main part of winter nutrients in this coastal zone comes from river loadings, these relationships could then be related to salinity to predict the distribution of chlorophyll a spring peak.

To improve the explanatory power of such relationships, re-introducing additional primary drivers in the chlorophyll-main nutrient relationship is necessary. Several authors have kept the rough nutrient TP or TN as "explanatory" variables, but have moved to a bi-linear model, 
using either the second limiting nutrient (e.g. Huszar et al., 2006) or a residence time proxy (the mean duration of periods of stable low flow when river bottom vegetation is the target, Biggs, 2000) as a second explanatory variable besides the first limiting nutrient concentration. However, since the pioneer work of Vollenweider (1975) in lakes, we are not aware of any similar attempt to derive a sound statistical model that links, for coastal marine waters, chlorophyll level to all its primary drivers, based on data and a conceptual model of eutrophication. As the WFD and the MSFD require the restoration of GES in eutrophicated coastal waters, refinements of such an algorithm to convert river nutrients into marine algal biomass is critical to avoid the negative economic consequences of unnecessary reductions in nutrient inputs from rivers. For instance, in the case of watersheds feeding turbid embayments and/or subject to strongly unbalanced $\mathrm{N}$ and $\mathrm{P}$ loadings, a realistic model should be able to conclude that no further reduction of the nutrient loadings would have to be done because of stoichiometric- and/or light-limitation. This paper contributes to this question in 3 ways: $1 /$ by deriving a mathematically invertible relationship between measured river nutrients and observed marine chlorophyll $a$, so as to deduce continental nutrient thresholds from marine chlorophyll thresholds 2 / by testing different spatial scales / geographical targets to assess GES 3/ by applying powerful linear programming to optimize the non-linear problem of nutrient loading reduction.

For the first question, our results show that taking into account the light availability and the $\mathrm{N}: \mathrm{P}$ ratio of the inorganic nutrients seems sufficient to re-align the data points along a log-log relationship between available nutrient and ChI P90. This relationship could be refined if the mean local residence time were taken into account. For instance, Balls et al. (1995) showed that despite a 5-fold increase in nitrogenous nutrients in the inflowing river over 30 years, a Scottish estuary had shown no increase in estuarine chlorophyll a concentrations, due to the short residence time of the estuary. Nixon (1983) showed that correcting the raw DIN river loading by dividing it by the mean hydraulic residence time of freshwater in the estuary allowed to obtain a log-log linear relationship between DIN concentrations measured in the 
estuary and "physically available" loadings. In this study, we did not add this causative variable in the assessment of "bioavailable nutrient", because in open $3 D$ shelf seas, the local water residence time cannot be simply deduced from local currents. For example, when a mesh of the grid model is embedded in gyres of various scales, the effective renewal rate of the water can be lowered.

Even with perfect understanding of the chlorophyll-nutrient relationship, it would remain difficult to fix a GES threshold value for chlorophyll $a$ as an indicator of eutrophication. Here we derived the GES threshold either from Chl P90 statistically estimated from satellitederived measures of chlorophyll a, or from national WFD thresholds. Sutula et al. (2017) have recently estimated a GES threshold from other indicators closely related to the deleterious ecological effects of eutrophication (low dissolved oxygen, Harmful Algal Bloom (HAB) abundance). For the naturally eutrophication-resistant San Francisco Bay (due to its high turbidity, its intense tidal mixing, and its large populations of filter-feeding clams), they estimated a first chlorophyll a GES threshold value at $13 \mu \mathrm{g} \cdot \mathrm{L}^{-1}$. Beyond this value, the risk of HAB increases and dissolved oxygen drops below $7 \mathrm{mg} \cdot \mathrm{L}^{-1}$. They gave a second threshold at $25-40 \mu \mathrm{g} \cdot \mathrm{L}^{-1}$, which induces a $50 \%$ risk of $\mathrm{HAB}$ problem and a drop of dissolved oxygen below $5 \mathrm{mg} \cdot \mathrm{L}^{-1}$. These thresholds appear to be quite high when compared to more sensitive, open coastal ecosystems: in the Gulf of Mexico, strong and harmful summer hypoxia is frequently observed although surface chlorophyll a does not exceed $12 \mu \mathrm{g} \cdot \mathrm{L}^{-1}$ during spring bloom, and $3 \mu \mathrm{g} \cdot \mathrm{L}^{-1}$ in mid-summer (Rabalais et al., 2007). Note that in this paper we consider the GES relatively to its phytoplanktonic component only, and do not include its green macroalgal component, which is more confined to the very shallow coastal strip. The optimum reduction of nitrogen loadings may be more drastic than presented here in case of local "green tide".

The second and third aspects are linked to the question of the transboundary nutrient transport that has been only recently addressed, because of the difficulty of assessing it from measurements at sea, except in the case of conservative chemical tracers, such as long-life radionuclides (Guegueniat et al., 1994). The most used approach for tracking, especially by 
engineers, is the Eulerian simulation of a conservative dye (Feddersen et al., 2016). The easy introduction of Eulerian conservative tracers in numerical models, as numerous as the different sources to be tracked, has allowed several authors to map the mean dilution plumes of some rivers over a decade (e.g. Lacroix et al., 2004). However, some scientists have recently used Lagrangian trajectories of numerous particles starting from the various sources under study to compute the fate of substances coming out of these sources; off-line weighting of these particles by some mass flow rate indicator allows mimicking the mixing of different substances brought by these rivers. Using this approach, Banas et al. (2015) mapped the respective roles of 15 river loadings in the DIN concentration in the Puget Sound, and the Portuguese participants to the EMoSEM project computed the fate of the 3 main rivers discharges in the Portuguese coastal zone (Desmit et al., 2015). The Eulerian approach however allows an easier production of various maps. Ménesguen et al. $\left(\right.$ submitted $^{\mathrm{a}}$ ) propose to define statistically different extents of a river plume, deduced from an Eulerian decadal 3D simulation of plume expansion under realistic flow rates and meteorological forcings, e.g. a "low water type" extent given by the decadal tracer $10^{\text {th }}$ percentile and a "high water type" extent given by the decadal tracer $90^{\text {th }}$ percentile. Especially in winter, the statistical plumes of big rivers may overlap and of course cross the frontiers between the national exclusive economic zones. Using the numerical tracking of non-conservative tracers (Ménesguen et al., 2006) allows an efficient assessment of the part of river-borne inorganic nutrients which are effectively included in marine organic material. But, if the optimization procedure of river concentrations is the main objective, we need the maps of the various river plumes in order to compute the effects of changing the river concentrations. Because eutrophication symptoms (high blooms, hypoxia...) are known to happen from spring to autumn, using "median" plumes (i.e. the decadal $50^{\text {th }}$ percentile) may be the best solution. The maps of mean water river content, estimated from $\mathrm{N}$ tracking results in this study, can be considered as a proxy of these "median" plumes. When the models are used after a spin-up lasting several years, the signatures of the different compartments containing $\mathrm{N}$ or $\mathrm{P}$ coming from a river reach a globally stable annual cycle, 
whose mean shows a distribution not far from this "median" plume weighted by the ratio between concentrations in the river and in the oceanic background. Here, for instance, both ECO-MARS3D and MIRO\&CO models show that nitrogen content of phytoplankton in the southern half of the eastern English Channel is strongly influenced by the Seine group of rivers. Both also show that these rivers significantly contribute to the high nitrogen level in the axis of the Southern Bight of the North Sea in front of Belgium: about $20 \%$ for winter DIN (MIRO\&CO), about 25\% for the nitrogen content of phytoplankton (ECO-MARS3D). Even the remote Loire River contributes to up to $10 \%$ of the nitrogen content of phytoplankton in the English Channel. In contrast, the riverine contribution to the phosphorus content of phytoplankton computed by ECO-MARS3D exhibits a much smaller area of influence. This suggests that the current phosphorus river loads contribute considerably less than nitrogenous river loads to nutrient enrichment of the coastal zone, due to the strong reduction of phosphorus wastes which has already been performed (Romero et al., 2013). In the Reference situation, the atmospheric nitrogen enters for 20 to $25 \%$ into the winter DIN (result of $\mathrm{MIRO} \& \mathrm{CO})$ and for $10 \%$ to $20 \%$ into the nitrogen content of March-October phytoplankton over the continental shelf (result of ECO-MARS3D). In the Pristine situation, the relative contribution from the atmospheric depositions in winter DIN is considered as vanishing.

The top-down approach presented here is a static equilibrium one, i.e. it computes steady state distributed loadings, which ensure a pre-defined ecological status at sea. The transient time-course of the recovery in case of reduced river loadings is not affordable by this approach, although it is an important question in remediation strategies. Especially for nitrate, large groundwater bodies lying beneath the river watersheds are known to delay the response to forcing changes (Aquilina et al., 2012). In the bottom-up approach, assessing the expected duration of GES recovery is feasible, but would require a simulation of the groundwater long-term reservoir much more detailed than in the PyNuts-Riverstrahler watershed model. Including time constants variables (and constraints on them) in the topdown approach seems incompatible with its time-independent algebraic formulation. 


\section{Conclusion}

By modelling the river-ocean continuum in continental seas, we can track potentially limiting nutrients $(\mathrm{N}, \mathrm{P}, \mathrm{Si})$ from their source watersheds down to their final marine destination. In this work, two marine ecological models (ECO-MARS3D,MIRO\&CO) and one generic ecological model for European river-basins (PyNuts-Riverstrahler) have been combined and used first to reproduce the spatial distribution currently observed for winter nutrients (DIN and DIP) and phytoplankton chlorophyll a (Chl P90). Forcing these coupled models under a Pristine land use scenario allows to delineate the maximal gap between a purely "natural" situation and the present-day, strongly anthropogenically enriched, situation. A supplementary strength of this modelling approach is to get further insight in the respective roles of the numerous sources of nutrients (rivers, ocean, atmosphere) in the current eutrophication nuisances recorded in some marine coastal regions. Generally, a descriptor of theses nuisances (e.g. the Chl P90) responds non-linearly to river nutrient concentrations, so that back-estimating the maximum available nutrient concentrations in rivers to reach GES is not straightforward and often unfeasible indeed. This work proposes a first step in re-linearizing the relationship between the eutrophication descriptor and a revised form of its controlling nutrients (i.e. the fraction "bioavailable" for algal growth). This opens up the opportunity to use powerful linear optimisation methods to support quantitative recommendations about necessary reduction of the river nutrient loads to reach GES. 


\section{Acknowledgements}

This study has been realized in the frame of the EU-FP7 ERANET Seas-era EMoSEM project funded by the French Research Agency (ANR) and the Belgian Sciences Policy (BELSPO, contract SD/ER/11).

The authors are indebted to Météo-France and the Previmer project (for ECO-MARS3D) and the UK Met Office for providing atmospheric forcings and the European Centre for MediumRange Weather Forecasts (for MIRO\&CO) for their free supply of the meteorological forcings for the 2000-2010 period.

The authors are also grateful to Semeena Valiyaveetil and Jerzy Bartnicki from the Meteorologisk institutt (met.no) for providing fields of atmospheric deposition of nitrogen, and to Martin Marzloff (IFREMER, Centre de Bretagne) for having deeply improved the English text. 


\section{Literature cited}

Aquilina L., Vergnaud-Ayraud V., Labasque T., Bour O., Molénat J., Ruiz L., de Montety V., De Ridder J., Roques C., Longuevergne L., 2012. Nitrate dynamics in agricultural catchments deduced from groundwater dating and long-term nitrate monitoring in surfaceand groundwaters. Sci. Tot. Environ., 435-436, 167-178.

Artioli Y., Friedrich J., Gilbert A.J., McQuatters-Gollop A., Mee L.D., Vermaat J.E., Wulff F., Humborg C., Palmeri L., Pollehne F., 2008. Nutrient budgets for European seas: A measure of the effectiveness of nutrient reduction policies. Marine Pollution Bulletin, 56(9),1609-1617.

Balls, P. W., MacDonald, A., Pugh, K., Edwards, A. C., 1995. Long-term nutrient enrichment of an estuarine system: Ythan, Scotland (1958-1993). Environmental Pollution 90, 311-321.

Banas N.S., Conway-Cranos L., Sutherland D.A., MacCready P., Kiffney P., Plummer M., 2015. Patterns of river influence and connectivity among subbasins of Puget Sound, with application to bacterial and nutrient loading. Estuaries and Coasts, 38, 735-753.

Baretta-Bekker, H., Bot, P., Prins, T., Zevenboom,W., 2008. Report on the Second Application of the OSPAR Comprehensive Procedure to the Dutch Marine Waters. Report by the Netherlands. 79 p., www.ospar.org

Beusen A.H.W., Bouwman A.F., Van Beek L.P.H., Mogollon J. M., Middelburg, J. J., 2016. Global riverine $\mathrm{N}$ and $\mathrm{P}$ transport to ocean increased during the 20th century despite increased retention along the aquatic continuum, Biogeosciences, 13, 2441-2451, doi:10.5194/bg-13-2441-2016 
Biggs B.J.F., 2000. Eutrophication of streams and rivers: dissolved nutrient-chlorophyll relationships for benthic algae. Journal of the North American Benthological Society, 19(1), 17-31.

Billen G., Dessery S., Lancelot C., Meybeck M., 1989. Seasonal and interannual variations of nitrogen diagenesis in the sediments of a recently impounded basin. Biogeochemistry 8:73100.

Billen G., Lassaletta L., Garnier J., Le Noë J., Aguilera E., Sanz-Cobena A. (in press). Opening to distant markets or local reconnection of agro-food systems? Environmental consequences at regional and global scales. In Lemaire G., Carvalho P., Kronberg S., Recous S. (eds), Sustainable Farming Systems. Chapter VI, 2. Elsevier

Billen G., Servais P., 1989. Modélisation des processus de dégradation bactérienne de la matière organique en milieu aquatique. In: Bianchi M., Marty D., Bertrand J.C., Caumette P., Gauthier M. (eds), Micro-organismes dans les écosystèmes océaniques. Masson, Paris, p 219-245.

Billen, G., Silvestre , M., Grizzetti, B., Leip, A., Garnier, J., Voss, M., Howarth, R., Bouraoui, F., Lepisto, A., Kortelainen, P., Johnes, P., Curtis, C., Humborg, C., Smedburg, E., Kaste, O., Ganeshram, R., Beusen, A., Lancelot, C., 2011. Nitrogen flows from European watersheds to coastal marine waters. In: Press, C.U., ed. The European Nitrogen Assessment. Cambridge University Press, 271-297

Bouwman A.F., Bierkens M.F., Griffioen J., Hefting M.M., Middelburg J.J., Middelkoop H., Slomp C.P., 2013. Nutrient dynamics, transfer and retention along the aquatic continuum from land to ocean: towards integration of ecological and biogeochemical models. Biogeosciences, 10(1), 1-22. 
Cugier P., Billen G., Guillaud J.-F., Garnier J., Ménesguen A., 2005. Modelling the eutrophication of the Seine Bight (France) under historical, present and future nutrient loading. J Hydrol., 304, 381-96.

Danzig G.B., 1963. Linear Programming and Extensions. Princeton University Press, Princeton, N.J.

Desmit X., Lacroix G., Dulière V., Lancelot C., Gypens N., Ménesguen A., Thouvenin B., Dussauze M., Billen G., Garnier J., Thieu V., Silvestre M., Passy P., Lassaletta L., Guittard G., Théry S., Neves R., Campuzano F., Garcia C., Pinto L., Sobrinho J., Mateus M., Ascione Kenov I. 2015a. Ecosystem Models as Support to Eutrophication Management In the North Atlantic Ocean (EMoSEM). EMoSEM final report. 174pp.

Desmit X., Ruddick K., Lacroix G., 2015b. Salinity predicts the distribution of chlorophyll a spring peak in the southern North Sea continental waters. Journal of Sea Research 103:5974.

Desmit X., Thieu V., Billen G., Campuzano F., Dulière V., Garnier J., Lassaletta L., Ménesguen A., Neves R., Pinto L., Silvestre M., Sobrinho J.L., Lacroix G. (submitted, this issue). Reducing marine eutrophication may require a paradigmatic change.

Devlin M., Painting S., Best M., 2007. Setting nutrient thresholds to support an ecological assessment based on nutrient enrichment, potential primary production and undesirable disturbance. Mar. Pollut. Bull., 55, 65-73.

Diaz R.J., Rosenberg R., 2008. Spreading dead zones and consequences for marine ecosystems. Science, 968 321(5891):926-9 
Doney S.C., 2010. The growing human footprint on coastal and open-ocean biogeochemistry. Science, 976 328(5985):1512-6

Dulière V., Gypens N., Lancelot C., Luyten P., Lacroix G., 2017. Origin of nitrogen in the English Channel and Southern Bight of the North Sea ecosystems. Hydrobiologia, https://doi.org/10.1007/s10750-017-3419-5

Dworak T., Berglund M., Haider S., Leujak W., Claussen U., 2016. A comparison of European nutrient boundaries for transitional, coastal and marine waters. Report of the Working Group on ecological Status ECOSTAT, 76 p.

Feddersen, F., Olabarrieta M., Guza R. T., Winters D., Raubenheimer B., Elgar S., 2016. Observations and modeling of a tidal inlet dye tracer plume, J. Geophys. Res. Oceans, 121, doi:10.1002/ 2016JC011922.

Garnier J., Billen G., Hannon E., Fonbonne S., Videnina Y. \& Soulie M. (2002a)-Modeling transfer and retention of nutrients in the drainage network of the Danube River. Estuar. Coast. Shelf Sci., 54: 285-308.

Gohin F., 2011. Annual cycles of chlorophyll-a, non-algal suspended particulate matter, and turbidity observed from space and in-situ in coastal waters, Ocean Sci. 7: 705-732, doi:10.5194/os-7-705-2011.

Guegueniat P., Bailly du Bois P., Gandon R., Salomon J.-C., Baron Y., Leon R., 1994. Spatial and temporal distribution (1987-91) of 125Sb used to trace pathways and transit times of waters entering the North Sea from the English Channel. Estuar. Coast. Shelf Sci. 39 59-74. 
Huszar, V., Caraco N., Roland F., Cole J., 2006. Nutrient-chlorophyll relationships in tropical-subtropical lakes: Do temperate models fit? Biogeochemistry 79: 239-250.

Jones, R. A., Lee G. F., 1986. Eutrophication modeling for water quality management: an update of the Vollenweider-OECD model., World Health Organ. Wat. Qual. Bull. 11(2):67-74, 118.

Kemp WM, Boynton WR, Adolf JE, Boesch DF, Boicourt WC, Brush G, Cornwell JC, Fisher TR, Glibert PM, Hagy JD, Harding LW, Houde ED, Kimmel DG, Miller WD, Newell RIE, Roman MR, Smith EM, Stevenson JC. Eutrophication in Chesapeake Bay: Historical trends and ecological interactions. Mar Ecol Prog Ser. 2005;303:1-29

Lacroix G., Ruddick K., Ozer J., Lancelot C. 2004. Modelling the impact of the Scheldt and Rhine/Meuse plumes on the salinity distribution in Belgian waters (Southern North Sea). Journal of Sea Research, 52: 149-163.

Lacroix G., Ruddick K., Park Y., Gypens N., Lancelot C., 2007. Validation of the 3D biogeochemical model MIRO\&CO with field nutrient and phytoplankton data and MERISderived surface chlorophyll a images. Journal of Marine Systems, 64(1-4): 66-88.

Lancelot C., Billen G., 1985. Carbon-nitrogen relationship in nutrient metabolism of coastal marine ecosystem. Adv Aquat Microbiol 3: 263-321.

Lancelot C., Spitz Y., Gypens N., Ruddick K., Becquevort S., Rousseau V., Lacroix G., Billen G., 2005. Modelling diatom and Phaeocystis blooms and nutrient cycles in the Southern Bight of the North Sea: the MIRO model. Marine Ecology Porgress Series 289: 63-78. 
Lazure P, Dumas F., 2008. An external-internal mode coupling for a 3D hydrodynamical model for applications at regional scale (MARS). Advances in Water Resources 31(2): 233250.

Lenhart H., Desmit X., Große F., Mills D., Lacroix G., Los H., Ménesguen A., Pätsch J., Troost T., van der Molen J., van Leeuwen S., Wakelin S. 2013. Report on "distance to target" modelling assessment by ICG-EMO. OSPAR Eutrophication series N599.

Los F.J., Troost T.A., Van Beek J.K.L., 2014. Finding the optimal reduction to meet all targets-Applying Linear Programming with a nutrient tracer model of the North Sea. Journal of Marine Systems 131: 91-101.

Luyten P., 2011. COHERENS - A Coupled Hydrodynamical-Ecological Model for Regional and Shelf Seas: User Documentation. Version 2.0. RBINS-MUMM Report, Royal Belgian Institute of Natural Sciences.

McCauley, E., Downing, J.A, Watson, S., 1989. Sigmoid relationships between nutrients and chlorophyll among lakes. Can. J. Fish. Aquat. Sci. 46: 1171-1175.

Mateus M., Riflet G., Chambel P., Fernandes L., Fernandes R., Juliano M., Campuzano F., de Pablo H., Neves R., 2012. An operational model for the West Iberian coast: products and services, Ocean Science, 8: 713-732.

Ménesguen A., Cugier P., Leblond I., 2006. A new numerical technique for tracking chemical species in a multisource, coastal ecosystem, applied to nitrogen causing Ulva blooms in the Bay of Brest (France). Limnology and Oceanography 51(1, part 2): 591-601. 
Ménesguen A., Dussauze M., Dumas F. (submitted ${ }^{\mathrm{a}}$ ). Designing optimal scenarios of nutrient loading reduction in a WFD/MSFD perspective by using passive tracers in a biogeochemical3D mode of the English Channel/Bay of Biscay area.

Ménesguen A., Dussauze M., Dumas F., Thouvenin B., Lecornu F., Repécaud M., $\left(\right.$ submitted $\left.^{b}\right)$. Ecological model of the Bay of Biscay and English Channel shelf for ecological status assessment. Part 1: Nutrients, phytoplankton and oxygen.

Ménesguen A., Hoch T., 1997. Modelling the biogeochemical cycles of elements limiting primary production in the English Channel. I. Role of thermohaline stratification. Mar. Ecol. Prog. Ser. 146: 173-188.

Monbet, Y. 1992. Control of phytoplankton biomass in estuaries: A comparative analysis of microtidal and macrotidal estuaries. Estuaries 15(4), 563-571.

Nixon. S. W., 1983. Estuarine ecology - a comparative and experimental analysis using 14 estuaries and the MERL microcosms. Final report to the U.S. Environmental Protection Agency, Chesapeake Bay Program under grant n X-003259-01, Washington, D.C.

Paerl H.W., 2009. Controlling eutrophication along the freshwater-marine continuum: dual nutrient ( $\mathrm{N}$ and $\mathrm{P}$ ) reductions are essential. Estuaries and Coasts, 32, 593-601.

Perrot T., Rossi N., Ménesguen A., Dumas F., 2014. Modelling green macroalgal blooms on the coasts of Brittany, France to enhance water quality management. J. Mar. Sys., 132, 3853. 
Phillips G, Pietiläinen O-P, Carvalho L, Solimini A, Lyche Solheim A, Cardoso A.C., 2008. Chlorophyll-nutrient relationships of different lake types using a large European dataset. Aquat Ecol. 42(2) : 213-226.

Rabalais, N. N., Turner, R. E., Sen Gupta, B. K., Boesch, D. F., Chapman, P., Murrell, M. C., 2007. Hypoxia in the northern Gulf of Mexico: Does the science support the plan to reduce, mitigate, and control hypoxia?, Estuaries Coasts, 30, 753-772.

Radach G., Lenhart H.J., 1995. Nutrient dynamics in the North Sea: fluxes and budgets in the water column derived from ERSEM. Netherlands Journal of Sea Research 33(3): 301335.

Romero E., Garnier J., Lassaletta L., Billen G., Le Gendre R., Riou P., Cugier P. (2013) Large-scale patterns of river inputs in SW Europe: seasonal and interannual variations and potential eutrophication effects at the coastal zone. Biogeochemistry 113, 481-505.

Sirjacobs D., Alvera-Azcárate A., Barth A., Lacroix G., Park Y., Nechad B., Ruddick K., Beckers J-M. 2011. Cloud filling of ocean color and sea surface temperature remote sensing products over the Southern North Sea by the Data Interpolating Empirical Orthogonal Functions methodology. Journal of Sea Research. 65: 114-130.

Smith, E.L., 1936. Photosynthesis in relation to light and carbon dioxide. Proceedings of the National Academy of Sciences, 22: 504-511.

Sutula M., Kudela R., Hagy III J.D., Harding, Jr. L.W., Senn D., Cloern J.E., Bricker S., Berg G.M., Beck M., 2017. Novel analyses of long-term data provide a scientific basis for chlorophyll-a thresholds in San Francisco Bay, Estuarine, Coastal and Shelf Science, 197, 107-118. 
Thieu V., Silvestre M., Lassaletta L., GarnierJ., Billen G. Generic application of the Riverstrahler biogeochemical model to western EU-rivers. Submitted to Environmental Modelling \& Software

Timmermann, K., Markager, S., Gustafsson, K.E., 2010. Streams or open sea? Tracing sources and effects of nutrient loadings in a shallow estuary with a 3D hydrodynamicecological model. Journal of Marine Systems, 82(3): 111-121.

Troost T.A., Blaas M., Los F.J., 2013. The role of atmospheric deposition in the eutrophication of the North Sea: A model analysis. Journal of Marine Systems 125: 101-112.

Vollenweider, R. 1975. "Input-Output Models with Special Reference to the Phosphorus Loading Concept in Limnology." Schweiz. Z. Hydrolo 37: 53-83. 


\section{List of Tables}

Table 1. Mean 2000-2010 decadal DIN and DIP concentrations $\left(\mu \mathrm{mol} \mathrm{L} \mathrm{L}^{-1}\right)$ in 4 groups of rivers (as defined for ECO-MARS3D and MIRO\&CO respectively), in the present situation and after optimal reductions computed by the Simplex method for 3 different geographical targets and 2 levels of thresholds (rigorous and lenient). The optimization process has been based either on crude DIN (or DIP) marine concentrations ("N/P \& light free" columns) or only on "fully bioavailable" DIN and DIP together ("N/P \& light constrained" columns ). Cells in grey point to the nutrients which have been reduced (compared to present values) following the Simplex optimization. 


\section{List of Figures}

Figure 1. Map showing the geographical extent and the bathymetry of the two marine ecosystem models: ECO-MARS3D (black rectangle) and MIRO\&CO (red rectangle).

Figure 2. Map of the $2000-2010$ chlorophyll $90^{\text {th }}$ percentile over the OSPAR growing season (March-October inclusive) deduced from the daily SeaWiFS and MODIS satellite data on sea-surface chlorophyll.

Figure 3. Map of the rivers and major watersheds taken into account by the ECO-MARS3D model, in addition to the oceanic source and, for nitrogen, the atmospheric source. The filled colours correspond to the 4 groups of numerically-tracked terrestrial nutrient sources: WestFrench rivers (bluish), East-French rivers (yellowish), English rivers (greenish), BelgianDutch rivers (pinkiish).

Figure 4. Relation between light-limited (grey dots) and light and nutrient-limited (black dots) "bioavailable" DIN and DIP and the satellite-derived 90th percentile of surface chlorophyll over the 2000-2010 period, when the phytoplankton N/P ratio=16. The white lines give the semi-log linear regression through the black clouds.

Figure 5. Density function of the observed satellite $2000-2010$ chlorophyll $90^{\text {th }}$ percentiles

Figure 6. Relative contribution (\%) of atmospheric nitrogen deposits (upper panel, left), oceanic DIN (upper panel, right) and four groups of rivers to the nitrogen content of the surface marine phytoplankton, averaged on the 2000-2010 period (middle panel, left: English rivers, middle panel, right: Belgian-Dutch rivers, bottom panel, left: East-French rivers and bottom panel, right: West-French rivers). 
Figure 7. Relative contribution (\%) of three groups of rivers to the phosphorus content of the surface marine phytoplankton, averaged on the 2000-2010 period. English rivers (left), EastFrench rivers (middle) and West-French rivers (right).

Figure 8. Maps giving the percentage of marine water coming from the 4 groups of rivers in ECO-MARS3D (top panels) and MIRO\&CO (bottom panels).

Figure 9. Meshes of ECO-MARS3D grid (top panels) and MIRO\&CO grid (bottom panels) retained (in white) in the 3 types of geographical targets where GES is to be obtained.

Figure 10. Maps of winter DIN in the marine domains of ECO-MARS3D (upper panel) and MIRO\&CO (lower panel) in three river loading configurations: current situation (left panel), simple optimal river $\mathrm{N}$ loading reduction (Free mode, middle panel) and optimal, light- and $\mathrm{N}: \mathrm{P}$ stoichiometry-constrained, river $\mathrm{N}$ loading reduction (Constrained mode, right panel). Gray scale relates to concentrations below the GES threshold, color scale to concentrations above.

Figure 11. Maps of winter DIP in the marine domains of ECO-MARS3D (upper panel) and MIRO\&CO (lower panel) in three river loading configurations: current situation (left panel), simple optimal river $\mathrm{P}$ loading reduction (Free mode, middle panel) and optimal, light- and $\mathrm{N}: \mathrm{P}$ stoichiometry-constrained, river $\mathrm{P}$ loading reduction (Constrained mode, right panel). Gray scale relates to concentrations below the GES threshold, color scale to concentrations above. 


\begin{tabular}{|c|c|c|c|c|c|c|c|c|c|c|c|c|}
\hline \multirow{3}{*}{$\begin{array}{l}\text { Region } \\
\text { Name of the tracer } \\
\end{array}$} & \multicolumn{4}{|c|}{$0-50 \mathrm{~m}$ bathymetric strip } & \multicolumn{4}{|c|}{ WFD water masses together } & \multicolumn{4}{|c|}{ MSFD sub-regions together } \\
\hline & \multicolumn{2}{|c|}{ DIN } & \multicolumn{2}{|c|}{ DIP } & \multicolumn{2}{|c|}{ DIN } & \multicolumn{2}{|c|}{ DIP } & \multicolumn{2}{|c|}{ DIN } & \multicolumn{2}{|c|}{ DIP } \\
\hline & 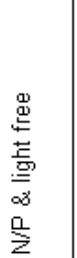 & 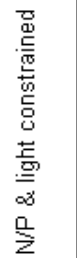 & 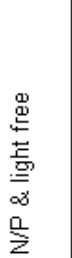 & 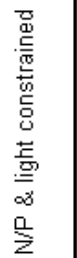 & 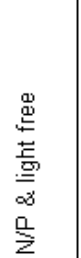 & 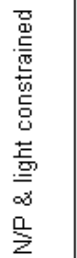 & 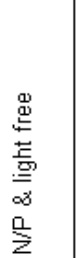 & 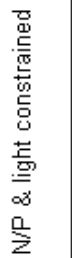 & 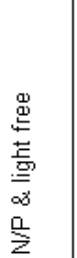 & 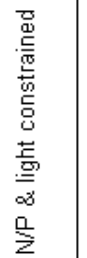 & 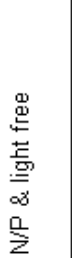 & 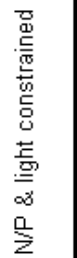 \\
\hline \multicolumn{13}{|c|}{ ECO-MARS3D grid } \\
\hline rigorous marine threshold ( $\mu \mathrm{mol} / \mathrm{L})$ & 9 & 9 & 0.56 & 0.56 & 9 & 9 & 0.56 & 0.56 & 9 & 9 & 0.56 & 0.56 \\
\hline above rigorous threshold, optimisable meshes & 2636 & 330 & 581 & 334 & 834 & 4 & 97 & 4 & 1658 & 29 & 127 & 29 \\
\hline above rigorous threshold, discarded meshes & 7 & 0 & 0 & 0 & 0 & 0 & 0 & 0 & 7 & 0 & 0 & 0 \\
\hline lenient marine threshold $(\mu \mathrm{mol} / \mathrm{L})$ & 19.5 & 19.5 & 0.65 & 0.65 & 19.5 & 19.5 & 0.65 & 0.65 & 19.5 & 19.5 & 0.65 & 0.65 \\
\hline above lenient threshold, optimisable meshes & 542 & 155 & 490 & 228 & 103 & 2 & 79 & 2 & 171 & 27 & 99 & 27 \\
\hline above lenient threshold, discarded meshes & 0 & 0 & 0 & 0 & 0 & 0 & 0 & 0 & 0 & 0 & 0 & 0 \\
\hline UK PRESENT $(\mu \mathrm{mol} / \mathrm{L})$ & 384 & 384 & 7.3 & 7.3 & 384 & 384 & 7.3 & 7.3 & 384 & 384 & 7.3 & 7.3 \\
\hline UK rigorously OPTIMISED ( $\mu \mathrm{mol} / \mathrm{L}$ ) & 127 & 384 & 7.3 & 7.3 & 136 & 384 & 7.3 & 7.3 & 384 & 384 & 7.3 & 7.3 \\
\hline UK Ieniently OPTIMISED $(\mu \mathrm{mol} / \mathrm{L})$ & 384 & 384 & 7.3 & 7.3 & 384 & 384 & 7.3 & 7.3 & 384 & 384 & 7.3 & 7.3 \\
\hline Holland-Belgium PRESENT ( $\mu \mathrm{mol} / \mathrm{L}$ ) & 197 & 197 & 8.0 & 8.0 & 197 & 197 & 8.0 & 8.0 & 197 & 197 & 8.0 & 8.0 \\
\hline Holland-Belgium rigorously OPTIMISED ( $\mu \mathrm{mol} / \mathrm{L}$ ) & 21 & 28 & 1.4 & 1.4 & 38 & 28 & 2.8 & 3.1 & 46 & 197 & 3.1 & 8.0 \\
\hline Holland-Belgium leniently OPTIMISED (umol/L) & 63 & 61 & 1.7 & 1.8 & 129 & 124 & 3.9 & 4.2 & 159 & 197 & 4.2 & 8.0 \\
\hline France-East PRESENT ( $\mu \mathrm{mol} / \mathrm{L}$ ) & 431 & 431 & 3.2 & 3.2 & 431 & 431 & 3.2 & 3.2 & 431 & 431 & 3.2 & 3.2 \\
\hline France-East rigorously OPTIMISED ( $\mu \mathrm{mol} / \mathrm{L})$ & 10 & 76 & 0.6 & 0.6 & 75 & 431 & 3.2 & 3.2 & 10 & 76 & 0.6 & 0.6 \\
\hline France-East leniently OPTIMISED ( $\mathrm{mmol} / \mathrm{L}$ ) & 19 & 86 & 0.6 & 0.6 & 264 & 431 & 3.2 & 3.2 & 19 & 86 & 0.6 & 0.6 \\
\hline France-West PRESENT $(\mu \mathrm{mol} / \mathrm{L}$ ) & 267 & 267 & 3.5 & 3.5 & 267 & 267 & 3.5 & 3.5 & 267 & 267 & 3.5 & 3.5 \\
\hline France-West rigorously OPTIMISED ( $\mu \mathrm{mol} / \mathrm{L})$ & 64 & 267 & 3.5 & 3.5 & 89 & 267 & 3.5 & 3.5 & 64 & 267 & 3.5 & 3.5 \\
\hline France-West leniently OPTIMISED ( $\mu \mathrm{mol} / \mathrm{L}$ ) & 218 & 267 & 3.5 & 3.5 & 267 & 267 & 3.5 & 3.5 & 218 & 267 & 3.5 & 3.5 \\
\hline \multicolumn{13}{|c|}{ MIRO grid } \\
\hline rigorous marine threshold $(\mu \mathrm{mol} / \mathrm{L})$ & 9 & 9 & 0.56 & 0.56 & 9 & 9 & 0.56 & 0.56 & 9 & 9 & 0.56 & 0.56 \\
\hline above rigorous threshold, optimisable meshes & 649 & 46 & 254 & 47 & 220 & 4 & 99 & 4 & 317 & 1 & 65 & 1 \\
\hline above rigorous threshold, discarded meshes & 0 & 0 & 0 & 0 & 0 & 0 & 0 & 0 & 0 & 0 & 0 & 0 \\
\hline lenient marine threshold ( $\mu \mathrm{mol} / \mathrm{L}$ ) & 19.5 & 19.5 & 0.65 & 0.65 & 19.5 & 19.5 & 0.65 & 0.65 & 19.5 & 19.5 & 0.65 & 0.65 \\
\hline above lenient threshold, optimisable meshes & 219 & 49 & 174 & 16 & 77 & 2 & 63 & 2 & 87 & 1 & 41 & 1 \\
\hline above lenient threshold, discarded meshes & 0 & 0 & 0 & 0 & 0 & 0 & 0 & 0 & 0 & 0 & 0 & 0 \\
\hline Scheldt PRESENT ( $\mu \mathrm{mol} / \mathrm{L}$ ) & 656 & 656 & 12.2 & 12.2 & 656 & 656 & 12.2 & 12.2 & 656 & 656 & 12.2 & 12.2 \\
\hline Scheldt rigorously OPTIMISED ( $\mathrm{mmol} / \mathrm{L}$ ) & 11 & 23 & 0.7 & 0.4 & 109 & 656 & 7.1 & 12.2 & 10 & 656 & 0.4 & 12.2 \\
\hline Scheldt leniently OPTIMISED $(\mu \mathrm{mol} / \mathrm{L})$ & 28 & 10 & 0.9 & 0.4 & 384 & 656 & 9.4 & 12.2 & 10 & 656 & 0.4 & 12.2 \\
\hline Rhine PRESENT ( $\mu \mathrm{mol} / \mathrm{L})$ & 259 & 259 & 6.4 & 6.4 & 259 & 259 & 6.4 & 6.4 & 259 & 259 & 6.4 & 6.4 \\
\hline Rhine rigorously OPTIMISED ( $\mu \mathrm{mol} / \mathrm{L})$ & 25 & 104 & 1.6 & 2.4 & 23 & 109 & 1.5 & 3.4 & 60 & 259 & 4.0 & 6.4 \\
\hline Rhine Ieniently OPTIMISED ( $\mathrm{mmol} / \mathrm{L}$ ) & 79 & 118 & 2.1 & 3.1 & 71 & 204 & 1.9 & 4.5 & 211 & 259 & 5.3 & 6.4 \\
\hline Thames PRESENT $(\mu \mathrm{mol} / \mathrm{L}$ ) & 1171 & 1171 & 45.0 & 45.0 & 1171 & 1171 & 45.0 & 45.0 & 1171 & 1171 & 45.0 & 45.0 \\
\hline Thames rigorously OPTIMISED ( $\mathrm{mmol} / \mathrm{L}$ ) & 49 & 336 & 3.2 & 13.9 & 163 & 1171 & 10.6 & 45.0 & 1171 & 1171 & 45.0 & 45.0 \\
\hline Thames Ieniently OPTIMISED ( $\mathrm{mol} / \mathrm{L})$ & 164 & 746 & 4.1 & 18.5 & 579 & 1171 & 14.2 & 45.0 & 1171 & 1171 & 45.0 & 45.0 \\
\hline Seine PRESENT ( $\mu \mathrm{mol} / \mathrm{L}$ ) & 456 & 456 & 4.7 & 4.7 & 456 & 456 & 4.7 & 4.7 & 456 & 456 & 4.7 & 4.7 \\
\hline Seine rigorously OPTIMISED ( $\mathrm{mmol} / \mathrm{L}$ ) & 25 & 142 & 1.6 & 1.9 & 46 & 456 & 3.0 & 4.7 & 25 & 142 & 1.6 & 1.9 \\
\hline Seine Ieniently OPTIMISED ( $\mu \mathrm{mol} / \mathrm{L}$ ) & 76 & 92 & 2.0 & 2.4 & 154 & 456 & 3.9 & 4.7 & 76 & 239 & 2.0 & 2.4 \\
\hline
\end{tabular}

Table 1 


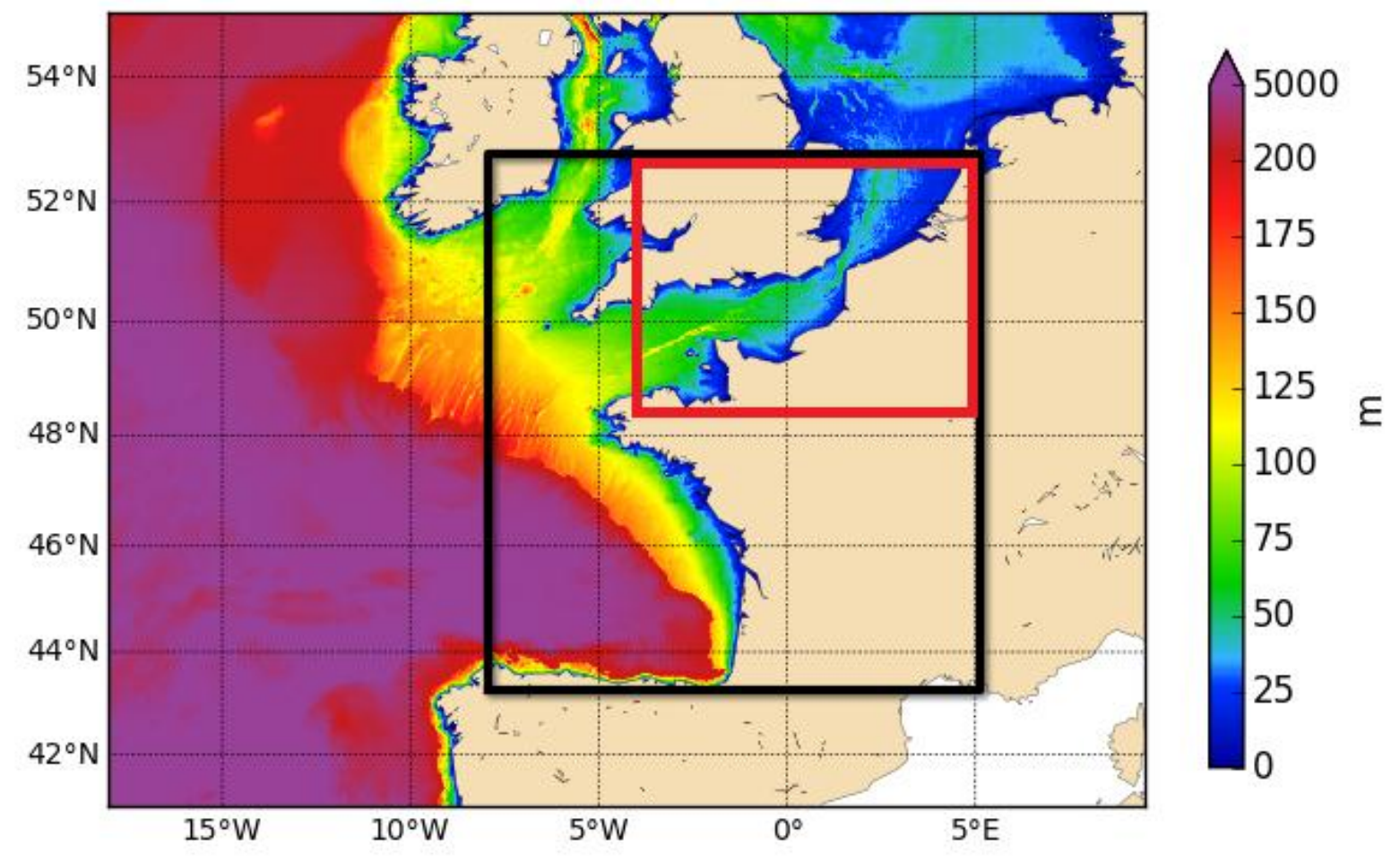

Figure 1 


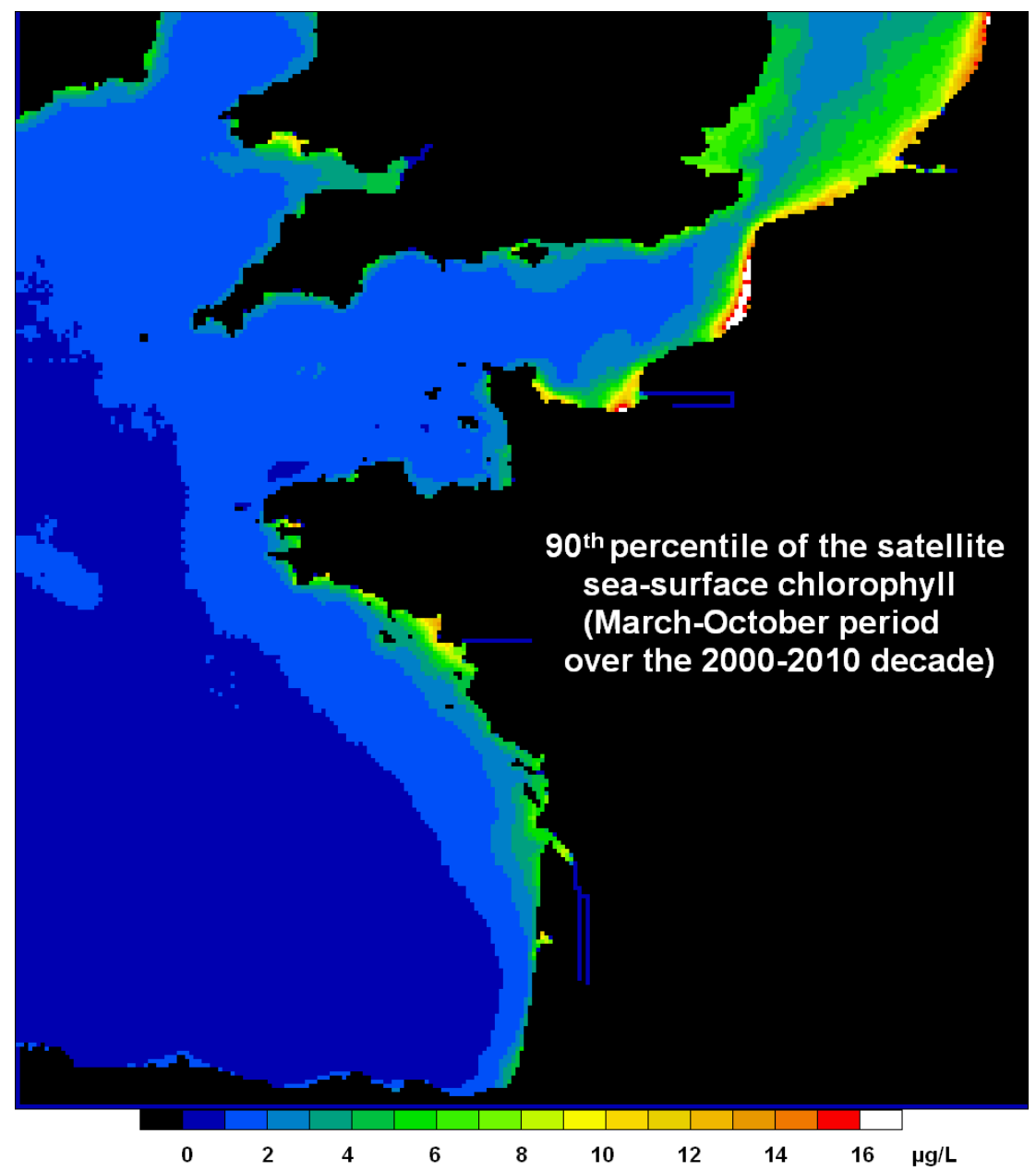

Figure 2 


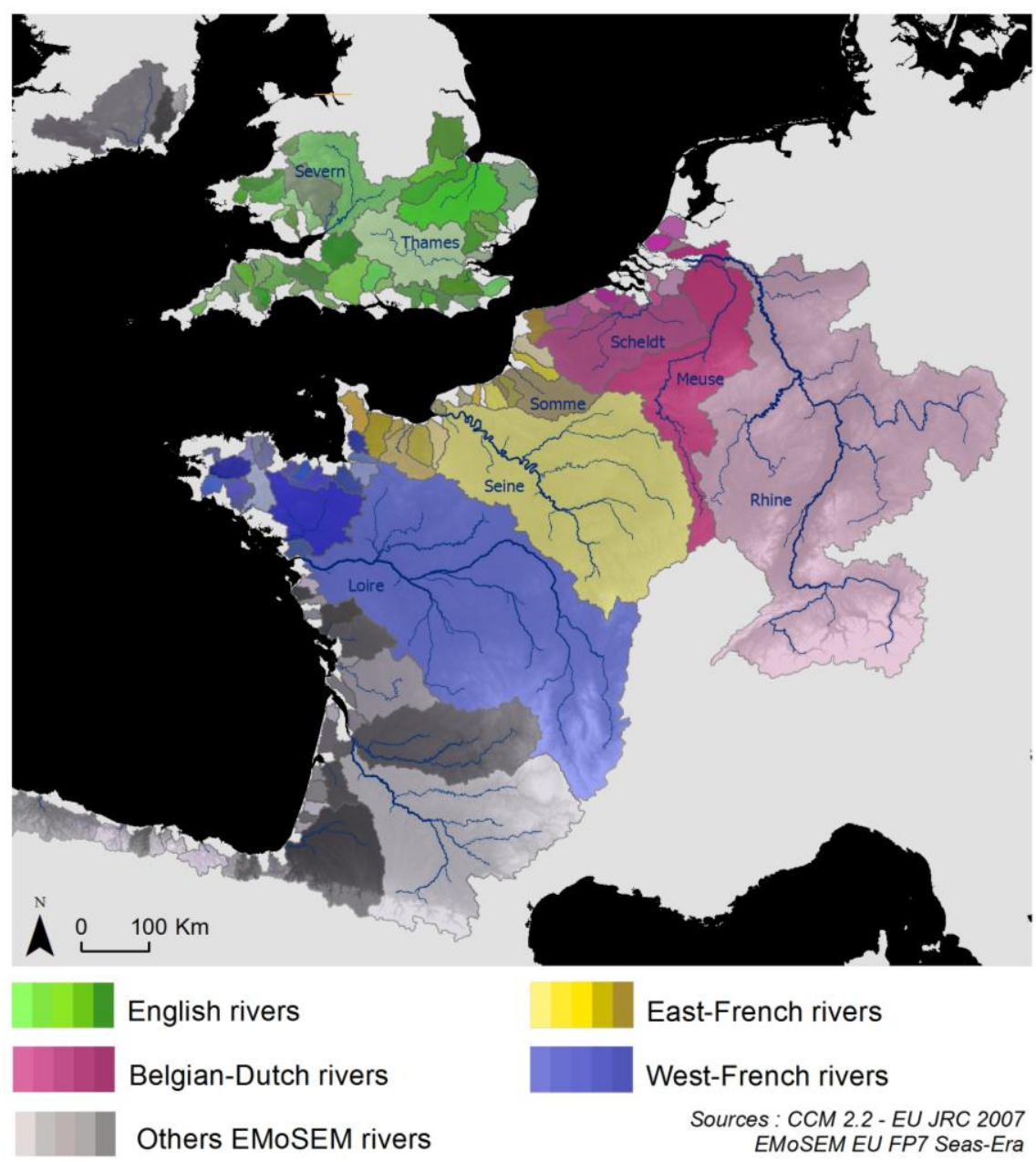

Figure 3 


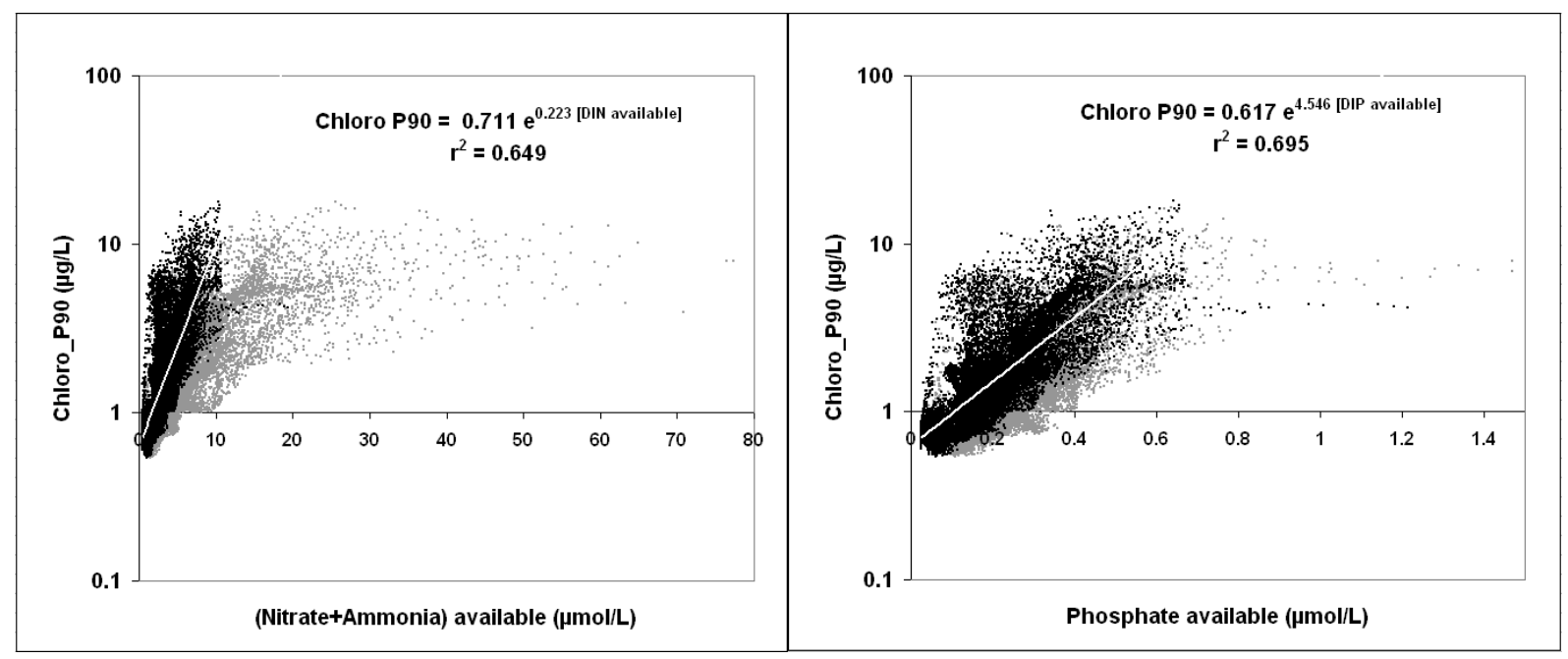

Figure 4 


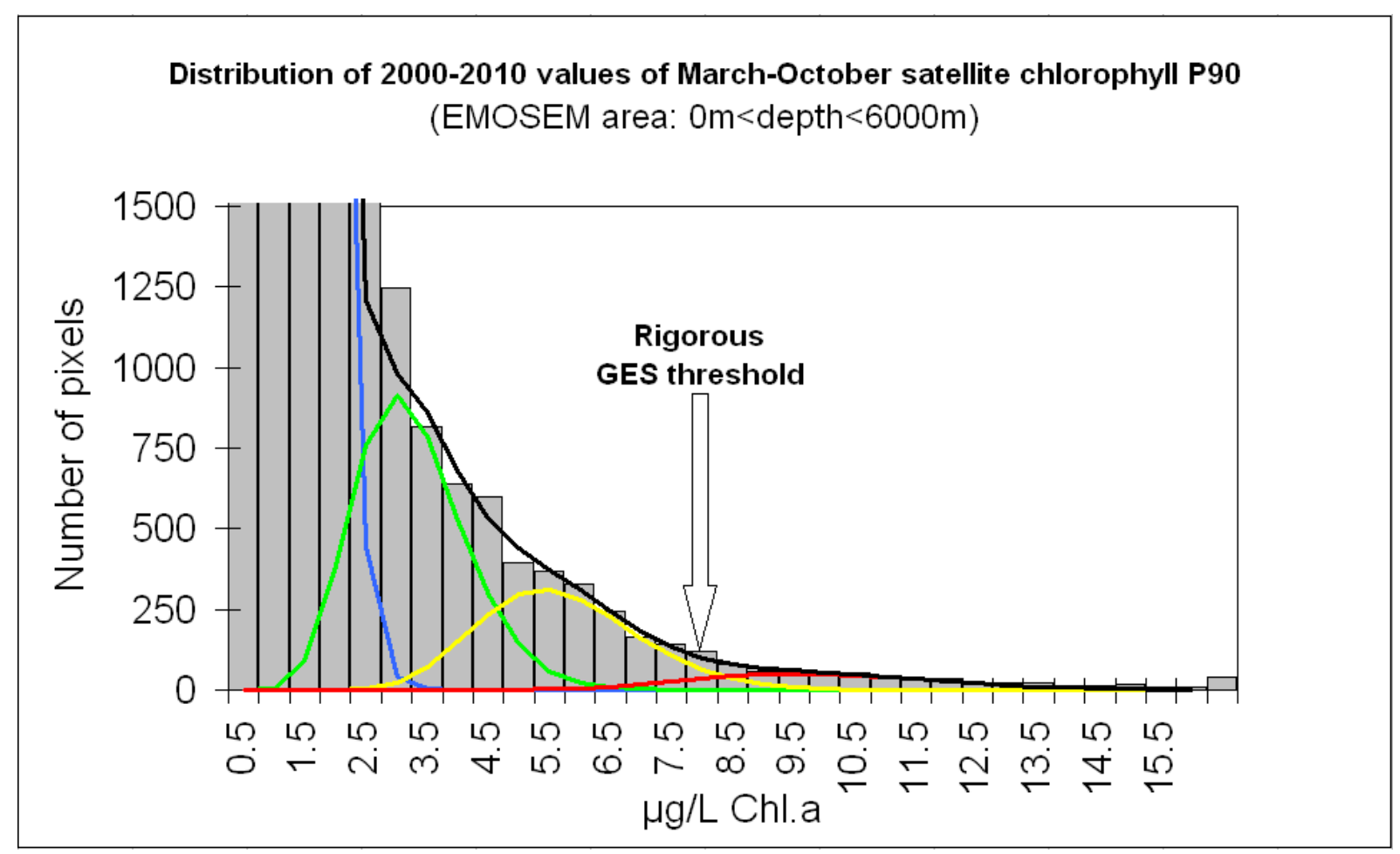

Figure 5 


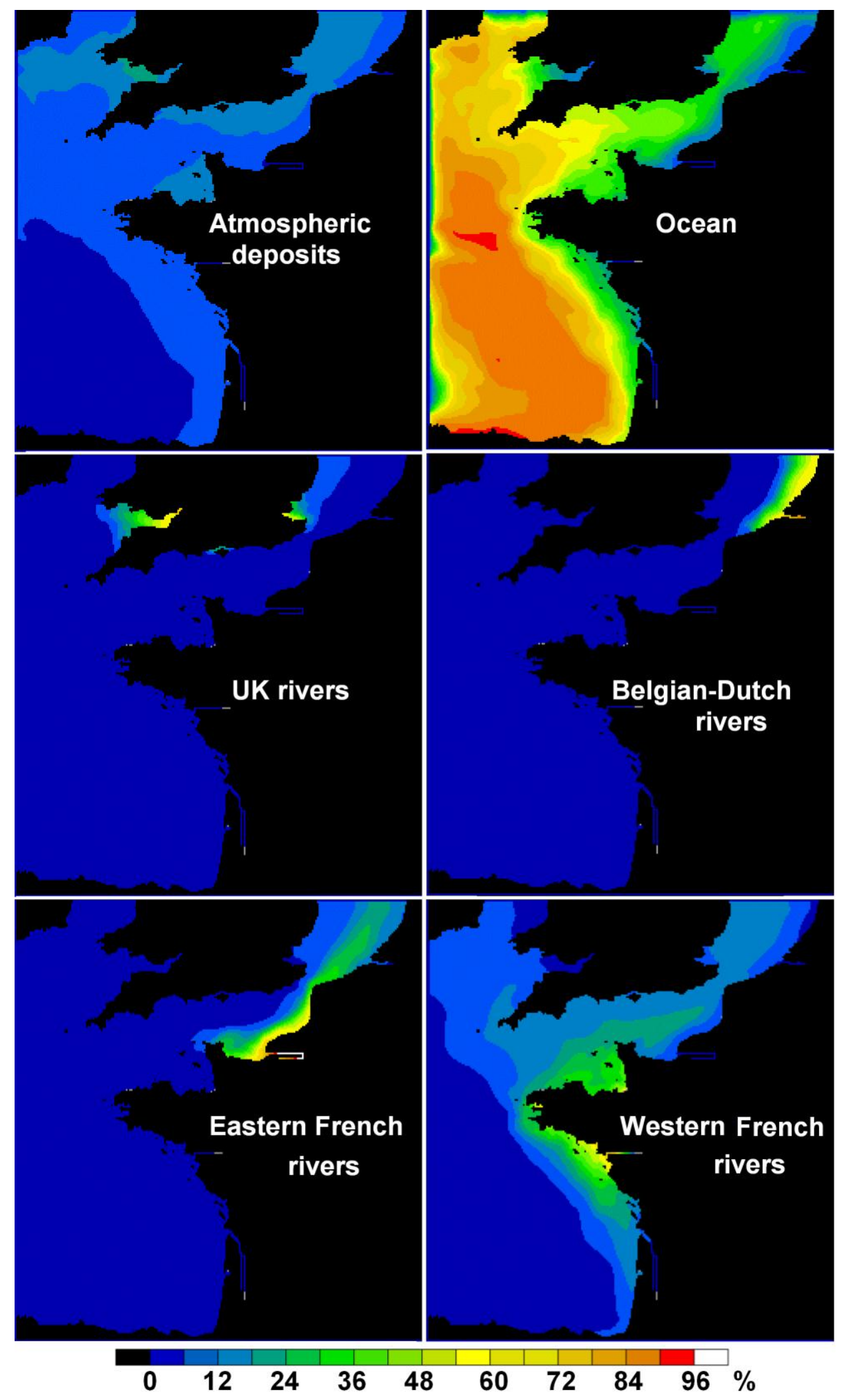

Figure 6 


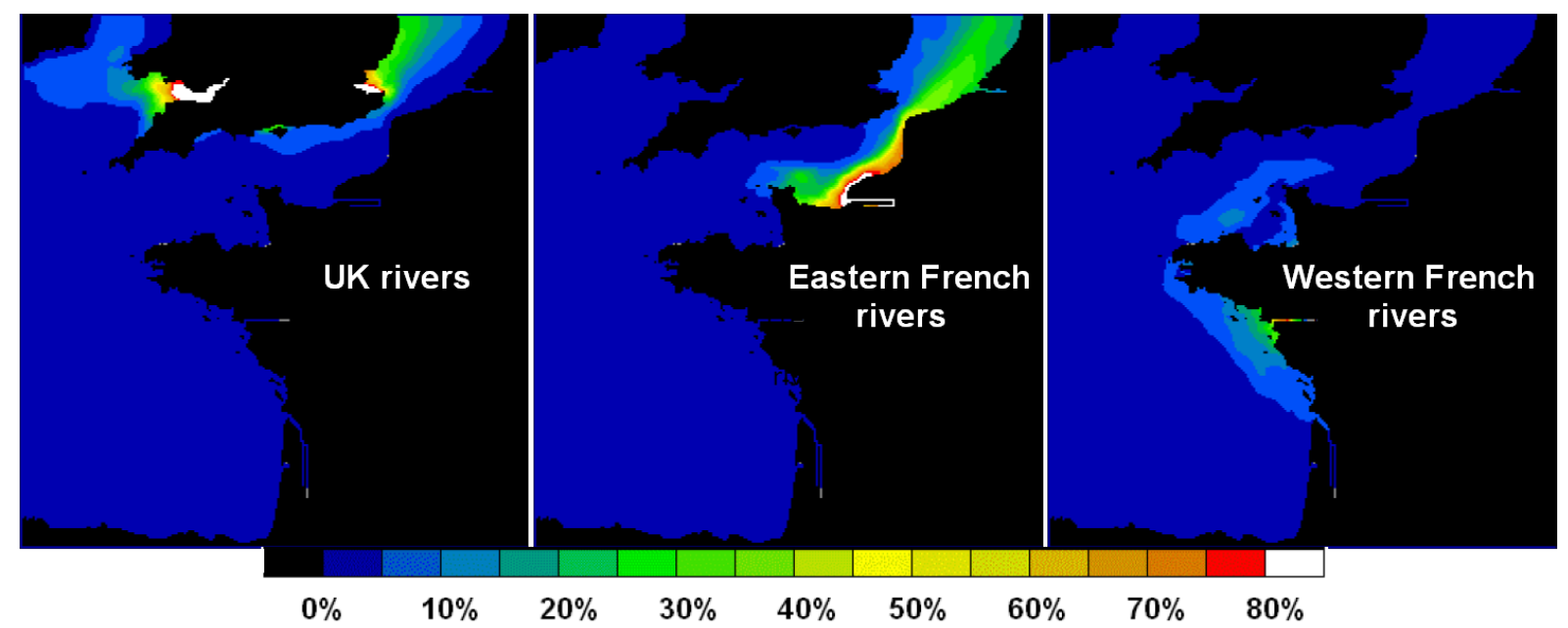

Figure 7 


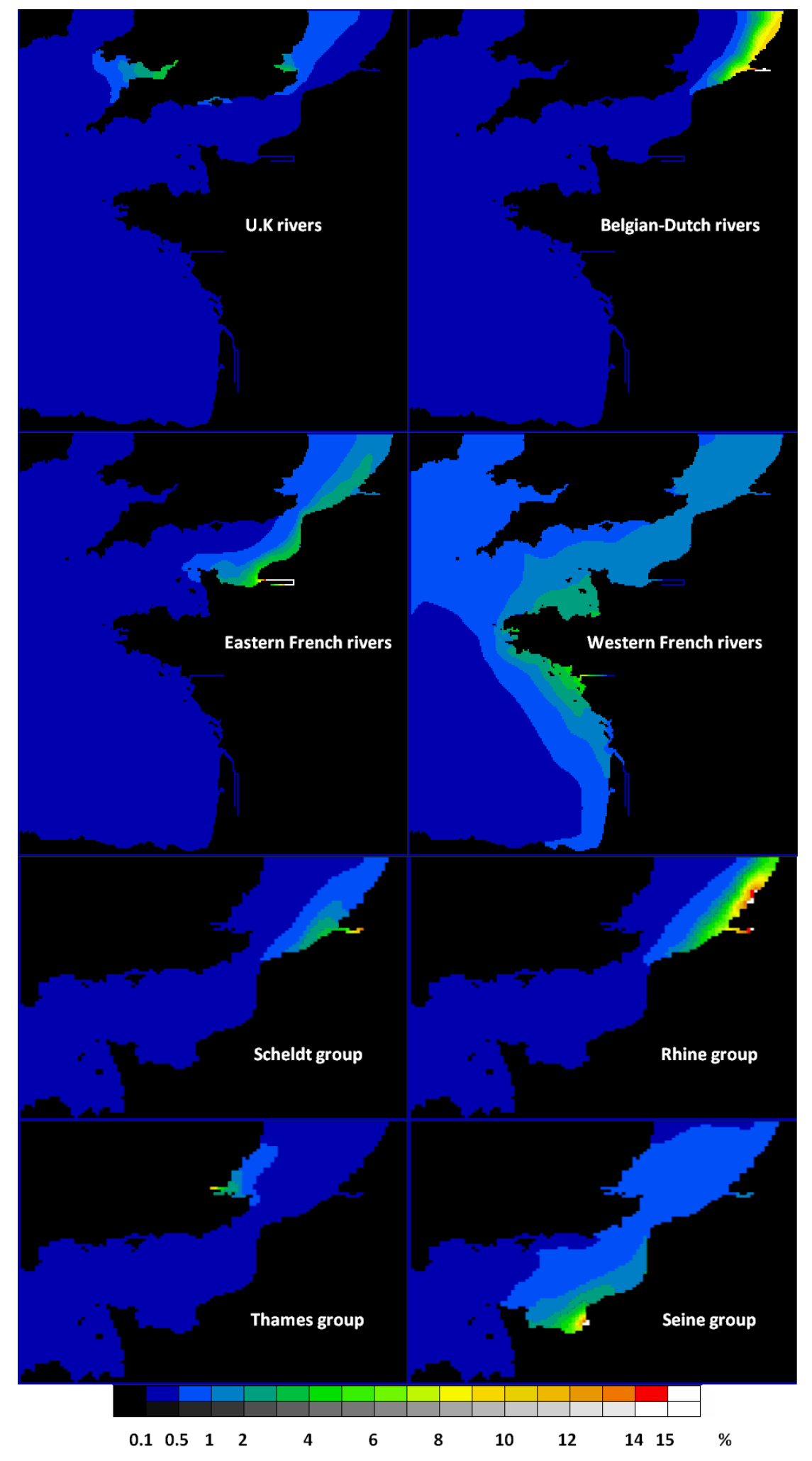

Figure 8 


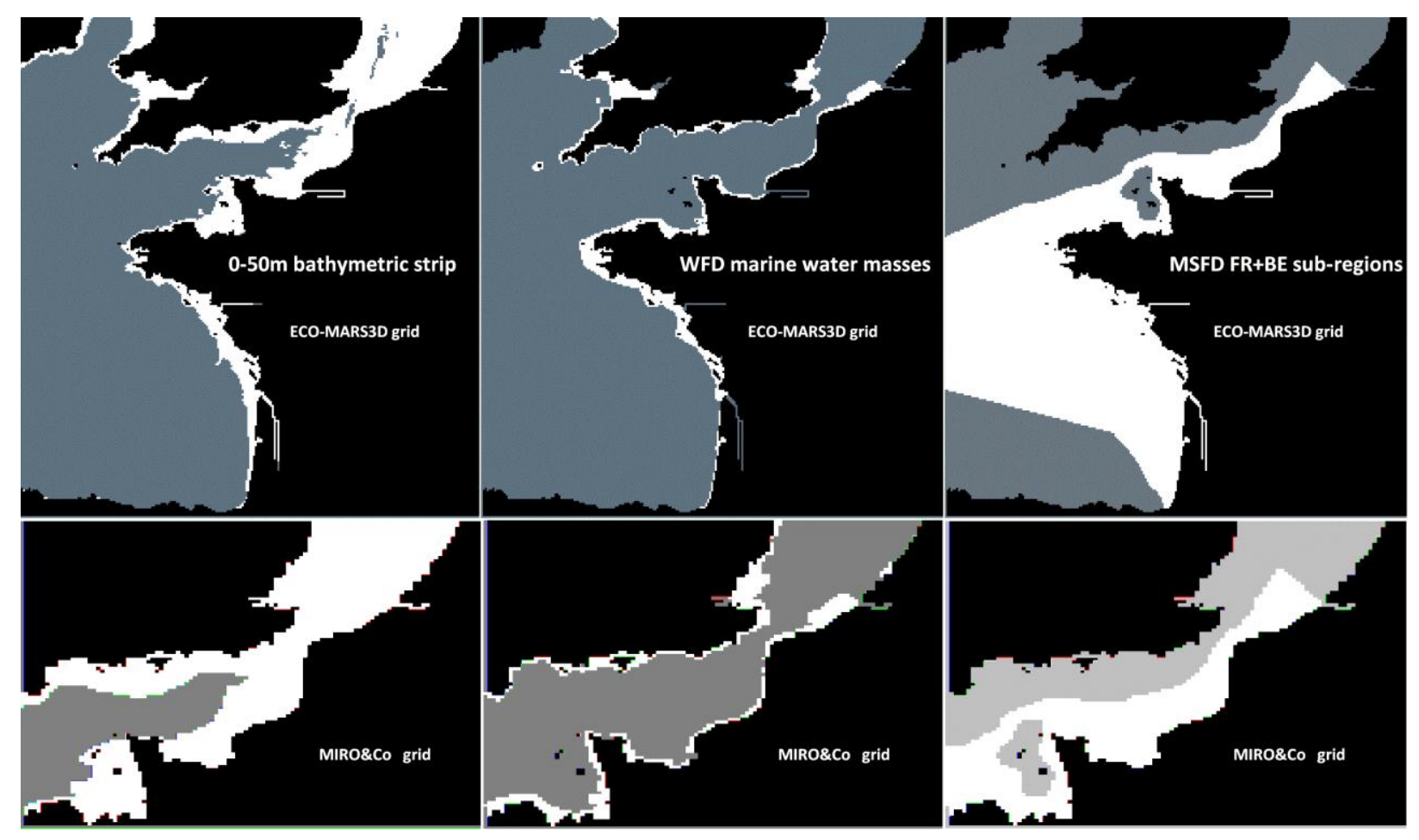

Figure 9 

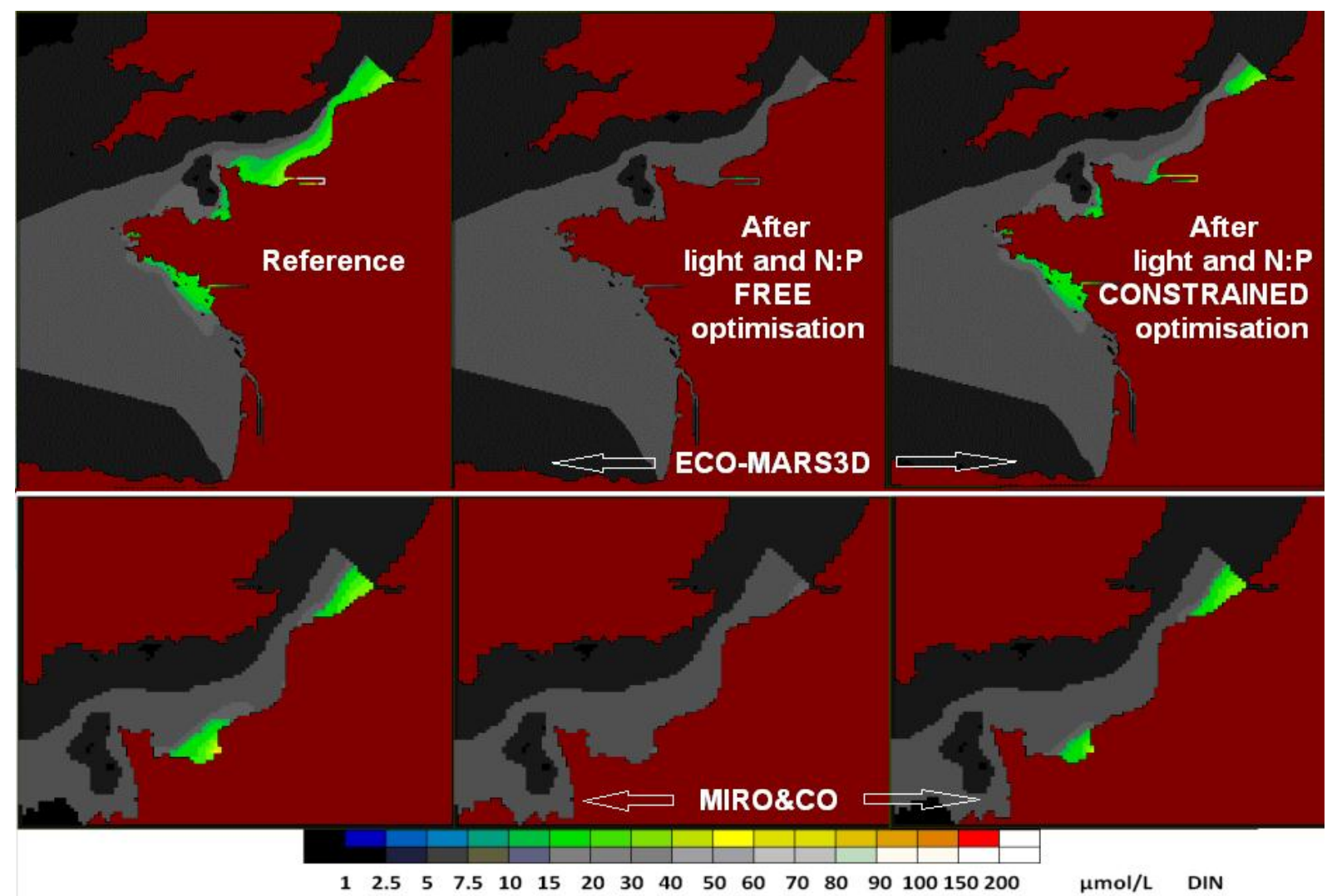

Figure 10 

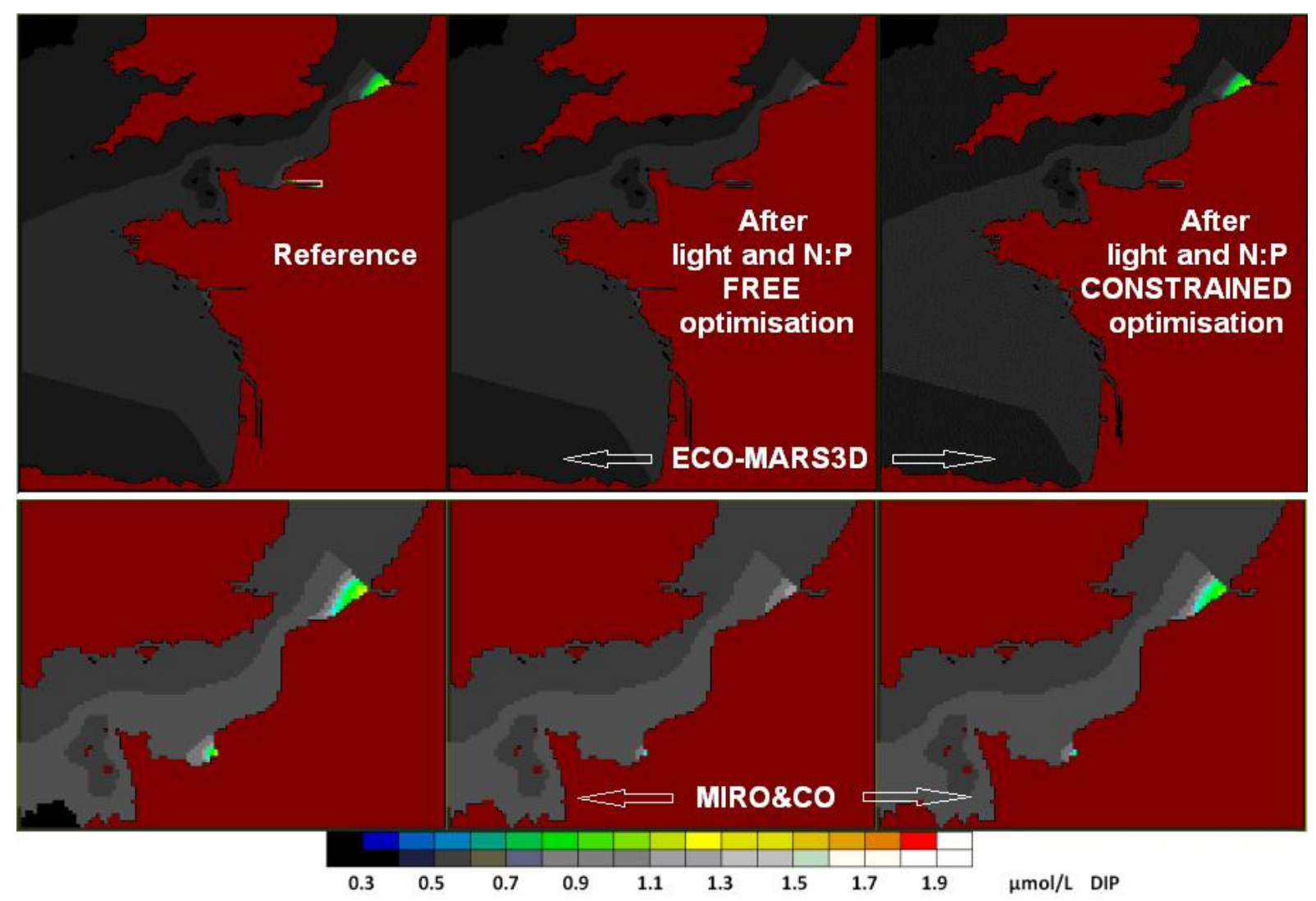

Figure 11 